\title{
A scoping review on the field validation and implementation of rapid diagnostic tests for vector-borne and other infectious diseases of poverty in urban areas
}

Lyda Osorio $^{1^{*}}$ (D), Jonny Alejandro Garcia ${ }^{1,2}$, Luis Gabriel Parra ${ }^{1,2}$, Victor Garcia ${ }^{1}$, Laura Torres ${ }^{1}$, Stéphanie Degroote ${ }^{3}$ and Valéry Ridde Rit $^{3,4}$

\begin{abstract}
Background: Health personnel face challenges in diagnosing vector-borne and other diseases of poverty in urban settings. There is a need to know what rapid diagnostic technologies are available, have been properly assessed, and are being implemented to improve control of these diseases in the urban context. This paper characterizes evidence on the field validation and implementation in urban areas of rapid diagnostics for vector-borne diseases and other diseases of poverty.

Main body: A scoping review was conducted. Peer-reviewed and grey literature were searched using terms describing the targeted infectious diseases, diagnostics evaluations, rapid tests, and urban setting. The review was limited to studies published between 2000 and 2016 in English, Spanish, French, and Portuguese. Inclusion and exclusion criteria were refined post hoc to identify relevant literature regardless of study design and geography. A total of 179 documents of the 7806 initially screened were included in the analysis. Malaria $(n=100)$ and tuberculosis $(n=47)$ accounted for the majority of studies that reported diagnostics performance, impact, and implementation outcomes. Fewer studies, assessing mainly performance, were identified for visceral leishmaniasis $(n=9)$, filariasis and leptospirosis (each $n=5$ ), enteric fever and schistosomiasis (each $n=3$ ), dengue and leprosy (each $n=2$ ), and Chagas disease, human African trypanosomiasis, and cholera (each $n=1$ ). Reported sensitivity of rapid tests was variable depending on several factors. Overall, specificities were high (> 80\%), except for schistosomiasis and cholera. Impact and implementation outcomes, mainly acceptability and cost, followed by adoption, feasibility, and sustainability of rapid tests are being evaluated in the field. Challenges to implementing rapid tests range from cultural to technical and administrative issues.
\end{abstract}

Conclusions: Rapid diagnostic tests for vector-borne and other diseases of poverty are being used in the urban context with demonstrated impact on case detection. However, most evidence comes from malaria rapid diagnostics, with variable results. While rapid tests for tuberculosis and visceral leishmaniasis require further implementation studies, more evidence on performance of current tests or development of new alternatives is needed for dengue, Chagas disease, filariasis, leptospirosis, enteric fever, human African trypanosomiasis, schistosomiasis and cholera.

Keywords: Communicable diseases, Diagnostic services, Point-of-care testing, Field evaluation, Sensitivity and specificity, Implementation, Evaluation studies, Urban health

\footnotetext{
* Correspondence: Iyda.osorio@correounivalle.edu.co

${ }^{1}$ Epidemiology and Population Health Research Group, School of Public

Health, Universidad del Valle, Calle 4B No. 36-00 Edif 118 Escuela de Salud

Pública, Universidad del Valle Campus San Fernando, Cali, Colombia

Full list of author information is available at the end of the article
}

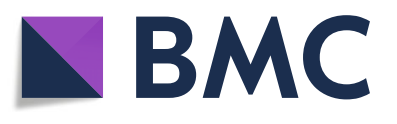

(c) The Author(s). 2018 Open Access This article is distributed under the terms of the Creative Commons Attribution 4.0 International License (http://creativecommons.org/licenses/by/4.0/), which permits unrestricted use, distribution, and

reproduction in any medium, provided you give appropriate credit to the original author(s) and the source, provide a link to the Creative Commons license, and indicate if changes were made. The Creative Commons Public Domain Dedication waiver (http://creativecommons.org/publicdomain/zero/1.0/) applies to the data made available in this article, unless otherwise stated. 


\section{Multilingual abstracts}

Please see Additional file 1 for translations of the abstract into six official working languages of the United Nations.

\section{Background}

A common scenario in health facilities in urban areas involves the following diagnostic process: a patient's arrival, triage, questionnaire and physical examination, presumptive diagnosis, request for laboratory analyses, taking of the sample, its transport to the laboratory, its processing, transmission of result, review by the treating physician, and case management decision. This process is likely to have varying turnaround times, some too long to be acceptable in relation to the expected needs of the patient, the physician, and the health system. For infectious diseases, there is a recognized need for speed in this process, as timely correct treatment can improve patients' probability of survival and prevent long-term complications and further dissemination. Consequently, rapid diagnostics are being developed using a wide spectrum of technological platforms, including rapid microscopy, immunochromatography (lateral flow, dipstick, card, latex), molecular technologies (real-time polymerase chain reaction [PCR], arrays, mass spectrometry, nanotechnology), and microfluidics [1]. In 2004, a call was made to improve validation and prioritize research and development of rapid diagnostics for tropical infectious diseases in developing countries as a key element in case management both within and outside hospital settings, in public health surveillance, and in meeting world-wide control and elimination targets [2].

Research and development of rapid diagnostics for vector-borne diseases (VBDs) and other poverty-related infectious diseases have been hampered by lack of investment, weak and heterogeneous regulatory standards, and insufficient capacity for product development in endemic countries. Moreover, the clinical and public health impacts that available rapid diagnostics might have are impeded by the scant adequate evidence of their accuracy and implementation processes under real-life conditions in the various settings where these diseases occur [3]. These include urban settings where social and environmental determinants facilitate the emergence, re-emergence and dissemination of infectious diseases [4]. Hence, the objective of the present study was to summarize the evidence on field validation and implementation in urban areas of rapid diagnostics for VBDs and other infectious diseases of poverty to inform decision-makers and future research. This is part of a series of scoping reviews on urban health and VBDs.

\section{Methods}

Description of the Delphi process used to select the topic of the scoping review

To decide on topics for scoping reviews on urban health and VBDs, we used an eDelphi survey to select the six topics considered of highest priority by a panel of 109 international experts (43\% researchers; $52 \%$ public health decision-makers; $5 \%$ from the private sector). The eDelphi process consisted of three rounds: 1) participants suggested topics to consider; 2) the more than 80 topics suggested were rated from "1-eliminate" to "5-top priority"; and finally, 3) the 20 topics rated 4 or 5 by more than $65 \%$ of panelists were rated a second time. The present topic was the only one automatically retained at the end of the second round, have obtained the mean rating of $4.29 \pm 0.87$ and thereby being ranked first (rated 4 or 5 by $85.7 \%$ of panelists).

\section{Search strategy}

The search strategy was constructed to answer the research questions of what rapid diagnostic tests for VBD and other infectious diseases of poverty in urban areas have been evaluated and what those evaluations were and found [5]. Search terms were defined that described four key concepts: 1) VBDs and other infectious diseases; 2) urban area; 3) diagnostic technologies; and 4) characteristics of rapid diagnostic technologies, these terms were combined using Boolean operators OR (within key concepts) and AND (between key concepts). The search was conducted in the following databases: MEDLINE (PubMed), Cochrane Library (Wiley), EMBASE, LILACS, Global Health (Ovid), WHOLIS, Opengray, and Scopus (Additional file 2: Table S1: Search strategy). Additional information was identified by manually screening the references of retrieved literature reviews and of some of the articles retained, as well as known international diagnostic programs, such as the World Health Organization (WHO) in vitro diagnostics prequalification process and the Special Programme for Research and Training in Tropical Diseases (TDR) diagnostic evaluation series $[6,7]$.

\section{Study selection}

The retrieved literature was downloaded into Zotero reference manager, and duplicates were identified and deleted. The entire library was exported to a Microsoft Excel $^{\circledR}$ (2016, Microsoft, Redmond, Washington, United States) screening template adapted from a free systematic review template [8]. References were distributed to two teams of two members each (JG/LGP and LT/VG), who independently reviewed titles and abstracts. During a pilot exercise, satisfactory agreement for the screening process was assessed between reviewers of the same team and between teams. A third independent reviewer (LO), who also performed the full-text screening, resolved discordant results. The study selection process was iterative. Studies published between 2000 and 2016 (last search conducted on October 31, 2016) in English, Spanish, French, and Portuguese were included. The following exclusion criteria were applied to titles, abstracts, 
and full texts: not relating to infectious diseases; none of our targeted infectious diseases; not conducted in humans or on human samples; not conducted in lowand middle-income countries (LMICs), or, if in a high-income country, not poverty related; no diagnosis of the disease/infection (e.g. diagnosis of complications or drug resistance); is a book; is in a rural area; diagnostics were used but not evaluated (e.g. to measure prevalence of disease/infection); the diagnostic intervention was not a biomarker (e.g. clinical algorithm or X-rays); it was not a field evaluation. The inclusion and exclusion criteria for rapid tests and urban area were refined post hoc during full-text screening to ensure objective definitions were followed. First, rapid diagnostic tests were defined using the WHO criteria [9]. One exception was made to include a rapid automated nucleic acid amplification test for tuberculosis (Xpert ${ }^{\circ} \mathrm{MTB} / \mathrm{RIF}$ ), as it is endorsed by WHO [10]. Second, it was not feasible to apply a standard definition of urban area, because what constitutes an urban population differs between countries and even within countries over time [11], and details of study settings in the retrieved documents were not consistent. Instead, we excluded studies only when they explicitly mentioned that the study area was exclusively rural or remote, or if they described the population as farmers, tribal, or nomadic. Otherwise, the study was included.

\section{Data extraction and analysis}

Characteristics, diagnostic performance, and implementation outcomes were extracted into a template using a Microsoft Excel ${ }^{\circ}$ spreadsheet. The following tools were used for data extraction: 1) Mixed Methods Appraisal Tool (MMAT) to describe key characteristics of qualitative, quantitative (randomized controlled, non-randomized, and descriptive), and mixed-methods studies [12]; 2) Template for Intervention Description and Replication (TIDieR) to describe the diagnostic interventions [13]; 3) Analysis of the transferability of health promotion interventions (ASTAIRE) to describe the epidemiological and sociodemographic characteristics of the study population [14]; and 4) diagnostic impact of tests, performance (sensitivity, specificity, predictive values), and implementation outcomes (acceptability, adoption, appropriateness, feasibility, fidelity, cost, penetration, and sustainability) [15] (Table 1). A descriptive analysis was done by disease.

\section{Results}

\section{Characteristics of included studies}

Of the 11441 documents that were identified from all databases plus 9 from other sources, 7806 were screened after duplicates were removed. From these, 6969 were excluded during titles/abstracts screening, 589 were excluded during full-text screening and 69 full texts could
Table 1 Definitions of diagnostic impact, performance, and implementation outcomes

Impact: effect of diagnostic test implementation on public health or patient-oriented outcomes

Performance: operational characteristics of diagnostic tests in relation to sensitivity, specificity, predictive values, and concordance with other tests

Acceptability: patient's and provider's perceptions of a diagnostic test being satisfactory

Adoption: intention, decision, or action to use a diagnostic test intervention

Appropriateness: perception of how well the diagnostic intervention meets the needs in a specific context

Feasibility: the extent to which the diagnostic intervention can be successfully used in a specific context

Fidelity: to what degree the diagnostic intervention was implemented as originally planned

Cost: monetary effort of the use of a diagnostic intervention in a specific context

Penetration: to what extent the diagnostic intervention reached the expected users

Sustainability: to what extent the diagnostic intervention is maintained or institutionalized

not be located. Hence, a total of 179 documents were included in the analysis, of which 143 were published in peer-reviewed journals, 34 were conference abstracts, and two were Master's theses (Fig. 1).

The majority of studies were about diagnosis of malaria $(n=100,56 \%)$ and tuberculosis $(n=47,26 \%)$, followed by visceral leishmaniasis $(n=9,5 \%)$, filariasis and leptospirosis ( $n=5$ each, 3\%), enteric fever and schistosomiasis ( $n=3$ each, 1.7\%), dengue and leprosy ( $n=2$ each, 1\%), and Chagas disease, African trypanosomiasis, and cholera ( $n=1$ each, $0.6 \%)$. More than half of the studies were carried out in Africa $(n=99,55 \%)$, followed by Asia $(n=41,23 \%)$, the Americas $(n=34$, $19 \%)$ and Europe $(n=3,2 \%)$. One study was conducted in countries on three continents (Africa, Americas, and Asia), and one study did not provide information (Fig. 2).

There was an increasing trend in the number of studies over time, with $83 \%(n=150)$ of the studies published after 2009. This trend was particularly observed for malaria (from 2009 onwards), tuberculosis (from 2010 onwards), and visceral leishmaniasis (from 2012 onwards) (Fig. 3).

All but six of the included studies were considered to have clear objectives. However, the reporting of the diagnostic intervention was often incomplete, particularly in relation to the level of training of the person performing the tests, which was not reported in most studies $(n=104,58 \%)$. Likewise, epidemiological and sociodemographic characteristics of the population were not described in 27 (15\%) studies. Outcomes of evaluation of rapid diagnostics were mainly reported in relation to their performance alone $(n=112,62.5 \%)$, while 


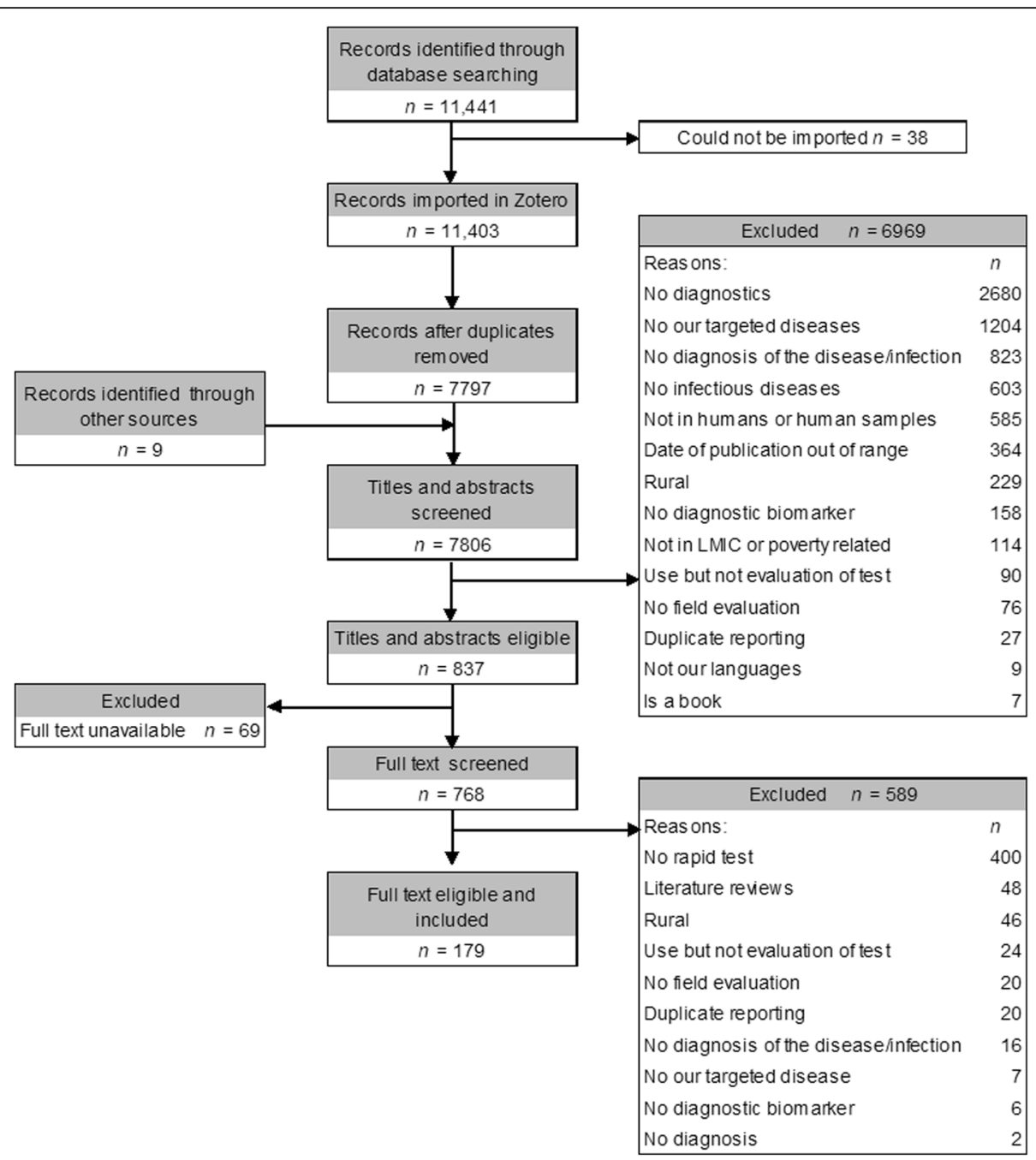

Fig. 1 Flow chart of included studies

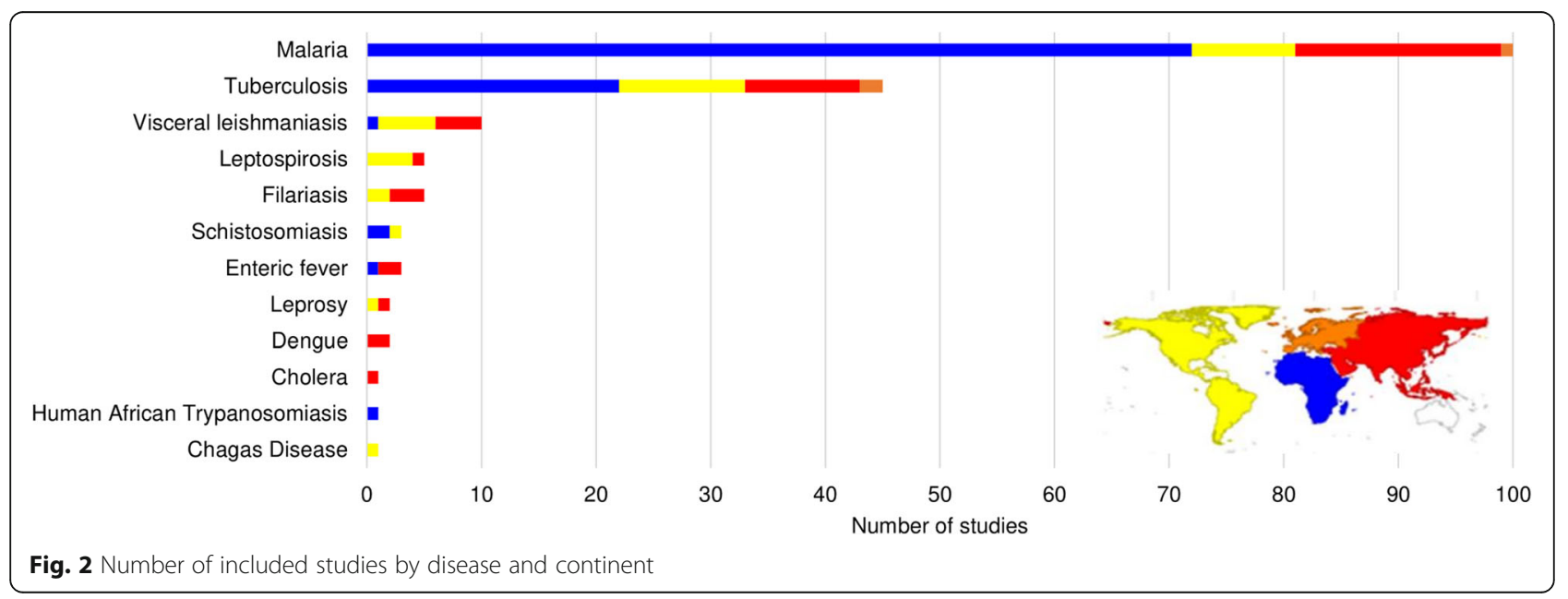




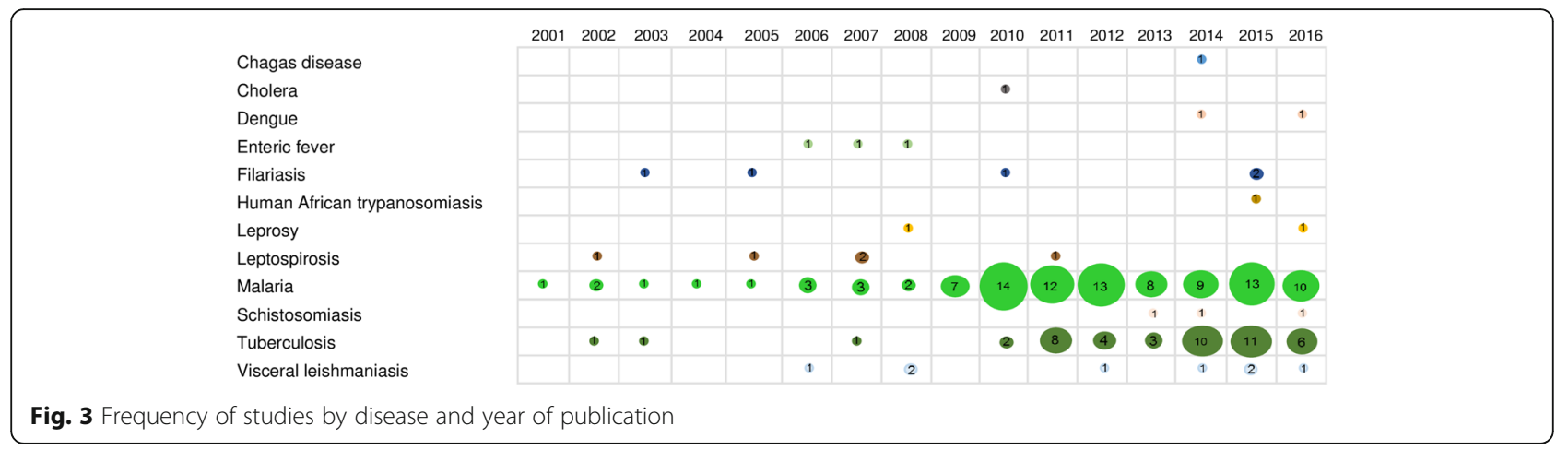

impact was evaluated alone in 12 studies (6.7\%) and together with performance in six studies (3.4\%). Cost and acceptability were the next characteristics evaluated either alone or in combination. There was no evaluation of fidelity or penetration. For every disease, there was at least one study that evaluated the performance of a test (Table 2).

Reference standards used to assess the performance of diagnostic tests were reported in all but 6 studies. Light microscopy was the diagnostic reference standard most frequently used in malaria and filariasis. For malaria, microscopy alone was used in 37 studies, and together with PCR in 12 studies. All four filariasis studies used microscopy as reference standard. More variability in the standards used was observed in tuberculosis, visceral leishmaniasis, leptospirosis, enteric fever and schistosomiasis. For tuberculosis, liquid culture alone $(n=7)$ was the most common reference test used followed by the combination of microscopy plus culture $(n=6)$. For visceral leishmaniasis, the combination of bone marrow microscopy and direct agglutination test was used in 2 studies. For leptospirosis, the microscopy agglutination test plus culture, and IgM enzyme-linked immunosorbent assay (ELISA) alone were used each in two studies. There was one study using the following reference tests: Culture alone or Widal test alone for enteric fever; and Kato-Katz alone, Kato-Katz plus ELISA, or urine microscopy for schistosomiasis. RTPCR was used for dengue, a combination of ELISA plus indirect haemagglutination (IHA) plus immunofluorescent antibody assay for Chagas disease, and culture for cholera (Additional file 3: Table S2: Details of included studies).

\section{Malaria}

There were 100 studies on malaria, of which 63 assessed performance of rapid tests. Among the evaluated assays were: OptiMAL-IT (DiaMed Basel, Switzerland, or DiaMed China Ltd., Hong Kong, China, or Flow Inc., Portland, OR, USA); Now ICT Malaria for Pf or Pf/Pv, ParaSight-F, Paracheck-Pf (Orchid Biomedical Systems, Verna, Goa, India), CareStart Pf/Pv, SD Bioline Malaria
Pf/Pan, Paramax-3 Pan/Pv/Pf, DiaSpot ${ }^{\circ}$ malaria (Acumen Diagnostics Inc., USA), Mal Card ${ }^{\mathrm{mx}}$, ICT Malaria Combo (ICT Diagnostics, Cape Town, South Africa), ParaHIT f (Span Diagnostics, Surat, India), PALUTOP+ 4 (All.Diag, Strasbourg, France), ICT malaria (Healgen Scientific LCC, Houston, TX, USA), ICT Parascreen test kit (Zephyr Biomedicals, Verna, Goa, India), ICT P.f./ P.v ${ }^{\text {rm }}$ (ICT; AMRAD-ICT, Brookvale, Australia), and Malaria Makromed (Makromed (Pty) Ltd., Johannesburg, South Africa). Reporting sensitivities and specificities were highly variable (from 2 to $100 \%$ and from 44.3 to $100 \%$, respectively), depending on study site, reference standard used, assay, parasitaemia, Plasmodium species (P. falciparum, P. vivax and P. knowlesi), whether hospital or community-based study, age of patients, and pregnancy (i.e., placental malaria) [16-78].

Impact was evaluated in 18 studies that reported that antimalarials were used in both rapid tests positive and negative patients; however, there was a decrease in use of antimalarials for presumptive treatment. Reductions in incidence of confirmed cases were observed plus a twofold or fourfold decrease in antimalarial prescription [17, 23, 59, 63, 79-91].

Acceptability was measured in 15 studies that showed a wide spectrum of responses to the use of rapid tests. In some studies, rapid tests were valued and appreciated by health workers, drug shop vendors, and communities, who in some cases were willing to purchase subsidized tests or trusted them, either because they were approved by relevant authorities and consistent with symptoms or because they were thought to reduce the cost of poor treatment. In contrast, in other scenarios, providers, health workers, and communities disliked or were suspicious of rapid tests. Among the reasons given for the low acceptability were: lack of trust in the accuracy of the tests (e.g. result clashes with patient's or provider's opinion); test positive after treatment; not able to quantify parasites; invalid results (control band non-reactive); high burden added to providers' work; no supplies, including gloves; patients' belief that they were being tested for HIV; or the cultural belief that the blood of 


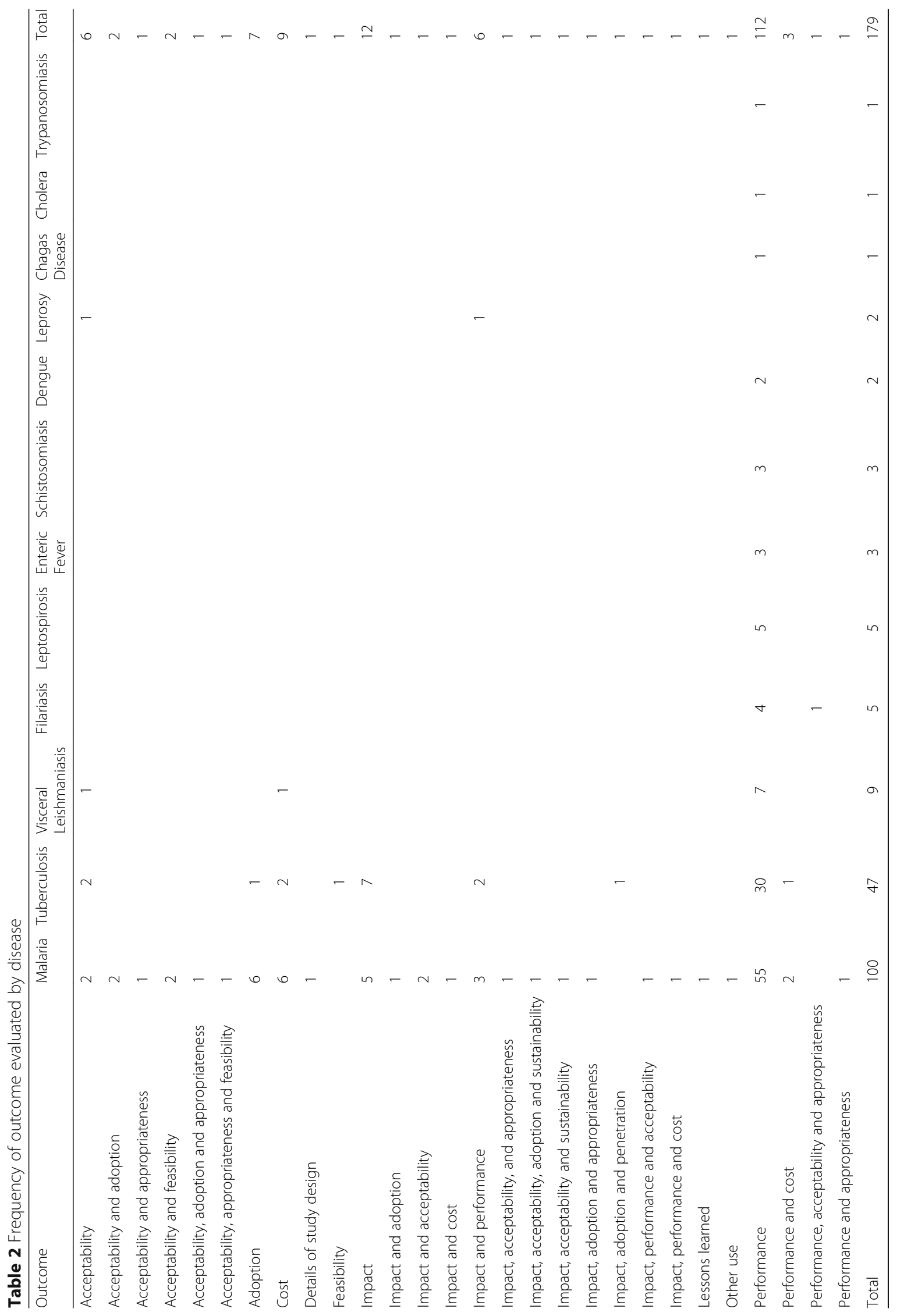


someone alive cannot be buried. Interventions were designed to improve acceptability of rapid tests [23, 81, 83, 84, 89, 91-100].

Studies of the adoption of rapid tests $(n=11)$ identified an increased number of facilities using the tests. Routine direct and/or indirect quality assessment of performance was included as part of diagnostic tests' adoption in some studies, but annual quality assurance assessments were found more often in the public than private sector. Problems with stock-outs of tests and paperwork were reported [84, 88, 95, 99-106].

There were 10 cost studies, of which nine presented results and one did not report the findings. The rapid test cost per correctly treated patient was found to be similar to the cost of microscopy, but lower than clinical diagnosis. The estimated cost of the rapid tests themselves ranged from USD 0.47 to 2.00 , and the implementation cost per kit (excluding the test), from USD 0.04 to 0.05 . It was reported that implementing rapid tests resulted in increased cost of treatment per patient in public facilities, despite drug savings in the health system. However, rapid tests were found to be more cost-effective than presumptive treatment in other studies, depending on sensitivity and costs of tests and prevalence of disease. Willingness to pay for rapid tests in Nigeria increased after they were tested [59, 60, 75, 86, 107-112].

Appropriateness, feasibility, or sustainability were evaluated in ten studies that reported challenges during implementation, including: inadequate transport; the need to cover long distances; inadequate compensation and supplies; and treatment-seeking behaviours associated with not undergoing diagnostic testing due to patients' not wanting to spend money on tests, preference for home-based over laboratory-based testing, not wanting to travel to a laboratory, and lack of perception of the need for a test. Even when using rapid tests, busy labs could not transmit results rapidly enough for clinical decision-making in real-time. Difficulties in sourcing and maintaining a continuous and adequate supply of tests at the local level were found to affect feasibility and sustainability of implementing rapid tests. The introduction of rapid tests into drug shops in Uganda was found to be feasible within a complex intervention that included guidelines for treatment and referral of negative patients, community sensitization about the test, regulation, or subsidization of the price of the tests, and a system for training and supervision to guarantee conformity of drug vendors [42, 80, 81, 83, 84, 93, 94, 96, 98, 99]. The study design and implementation of the rapid test in drug shops in Uganda and lessons learned were detailed in two papers $[113,114]$. For other uses, it was found that DNA can be successfully extracted and amplified from positive tests in the field [115]. There were positive features of rapid tests, such as their perceived ease of use, the ability to indicate the patient's name or code, and the ability to deposit reagents in same well (Additional file 3: Table S2: Details of included studies).

\section{Tuberculosis (TB)}

There were 47 studies on tuberculosis of which 22 evaluated the performance of Xpert ${ }^{\bullet} \mathrm{MTB} / \mathrm{RIF}$ and reported sensitivities ranging from 58.7 to $100 \%$ compared to culture in one or more spontaneous or induced sputum samples, and specificities near $100 \%$. Sensitivity in non-respiratory samples (including cerebrospinal fluid, pleural, peritoneal, pericardial, gastric juice, bone, and lymph nodes) was also high (>75\%). Sensitivity decreased in HIV-infected subjects and smear negative samples, but was not affected by anaemia when evaluated in HIV-infected subjects [116-137]. Alere Determine TB-LAM Ag (Alere Inc., Waltham, MA, USA), a lateral flow assay that detects the mycobacterial cell wall antigen lipoarabinomannan (LAM) in urine, showed low sensitivity of $28.2 \%$ (95\% CI: 19-39) against culture and 57.6\% (95\% CI: 46.468.3) against Xpert ${ }^{\circ}$ MTB/RIF in patients with HIV-associated TB with high specificity (> 98\%) [138].

Impacts of $\mathrm{Xpert}^{\oplus} \mathrm{MTB} / \mathrm{RIF}$ implementation in respiratory and non-respiratory samples and of TB-LAM were evaluated in eleven studies, which found a consistent increase in detection of TB cases, a decrease in time-totreatment of patients with rifampicin-resistant $\mathrm{TB}$, and a small decrease in TB-attributed mortality. Delay in patient diagnosis was not associated with $\mathrm{Ct}$ values of $\mathrm{Xpert}^{\circ} \mathrm{MTB} /$ RIF (Spearman $R^{2}=0.001 . P=0.612$ ) [118, 122, 139-147].

Three studies assessed the cost of rapid tests as part of diagnosis and treatment algorithms. They found that the largest cost driver was consumables: cartridges in the case of $\mathrm{Xpert}^{\oplus} \mathrm{MTB} / \mathrm{RIF}$, increasing the mean cost per TB case diagnosed threefold, but slightly less costly in MDR-TB case diagnosis. Other direct and indirect costs were related to transport, medical care, and time in health facility, which favoured the implementation of Xpert $^{\oplus}$ MTB/RIF [148-150].

The adoption of $\mathrm{Xpert}^{\oplus} \mathrm{MTB} / \mathrm{RIF}$ was found to be highly acceptable to lab technicians and improved the notification indicators in Brazil, although there were concerns around ensuring the necessary funding to sustain the intervention $[147,151]$. Other obstacles to implementation included lack of key documents-such as updated guidelines, concise and clear standard operating procedures (SOP), and training modules-as well as failures in identifying presumptive MDR-TB cases. It was reported that notification forms needed to be adapted to minimize errors when using $\mathrm{Xpert}^{\oplus} \mathrm{MTB} / \mathrm{RIF}$, and that a regular supply of cartridges and spare parts was required. It was felt that it was important to maintain the capacity to perform smear microscopy to follow up patients and to process samples that were too scanty to run Xpert ${ }^{\circ} \mathrm{MTB} /$ RIF. In addition, feasibility was linked to quality control, 
qualified staff, work organization, computerized labs, and staff replacement programs $[143,152,153]$.

The ICT Tuberculosis test (AMRAD Corporation, Melbourne, Australia), in an original (ICT1) and a manufacturer-modified version (ICT2), showed up to $83 \%$ sensitivity using whole blood. However, the combined sensitivity of microscopy and serology was 37.9\% in HIV-coinfected patients [154, 155]. The TB STAT $\mathrm{PAK}^{\circ}$ assay showed $63.4 \%$ sensitivity and $100 \%$ specificity in the Philippines $[156,157]$. A Mexican rapid immunologic test (PRIM) was 79.2\% (95\% CI: 67.2-87.5) sensitive and 100\% (95\% CI: 93.6-100) specific [158]. On-site TB IgG/IgM rapid test yielded $88 \%$ sensitivity and $55 \%$ specificity compared to Quantiferon [159]. We found one exploratory study with Hexagon chromatographic immunoanalysis [160]. The measurement of exhaled nitric oxide showed sensitivity and specificity below $80 \%$ [161] and one field study of the amplified Mycobacterium tuberculosis direct (AMTD) test (Gen-Probe, San Diego, CA, USA) showed higher sensitivities which varied in smear positive and negative HIV-infected patients [162]. (Additional file 3: Table S2).

\section{Visceral leishmaniasis}

Nine studies on visceral leishmaniasis evaluated the performance, cost, or acceptability and appropriateness of commercial or in-house rapid tests. The sensitivity of recombinant $\mathrm{K} 39$ protein (rK39) rapid tests, such as IT-LEISH $^{\circ}$ (Bio-Rad Laboratories, Hercules, CA, USA, and DiaMed, Cressier, Switzerland) and Kalazar Detect ${ }^{\circ}$ (InBios International, Seattle, WA, USA) ranged from 72.4 to $87.59 \%$ and specificity, from 99.6 to $100 \%$ in blood or serum [163, 164]. HIV infection decreased sensitivity to $60 \%$ [163], but performance was not affected by malnutrition [165]. The reproducibility of immunochromatographic strip rK39 was very low (kappa 0.14) in one study in Brazil [166]. In urine samples, the rK39 rapid test and KAtex ${ }^{\circ}$ (Kalon Biological, Guildford, UK), a latex agglutination test based on the detection of a low-molecular weight $(5-20 \mathrm{kDa})$ heat-stable carbohydrate antigen, were evaluated. The sensitivity of the rK39 rapid test was 100\% (95\% CI: $94.95-100 \%)$ and specificity was $86.33 \%$ (95\% CI: 79.23-91.36\%) [167] and sensitivity of KAtex ${ }^{\odot}$ was $77.77 \%$ and specificity was 98.24\% [168]. In an endemic area in Brazil, the direct cost of IT-LEISH ${ }^{\circ}$ was estimated to be USD 6.62 compared to USD 6.72 for the Kala-Azar Detect ${ }^{\circ}$ rapid test [169]. The IT LEISH was found to be more appropriate to implement in the same endemic area due to its use of capillary blood, the positive reaction of $96 \%$ of patients to the finger prick blood collection, and its acceptability among healthcare professionals [170]. The sensitivity of an in-house latex agglutination test based on A2 antigen (A2LAT) or promastigote lysates proteins (proLAT) were $88.4 \%$ (both tests), and specificity was $93.5 \%$ for A2LAT and $100 \%$ for proLAT [171]. (Additional file 3: Table S2: Details of included studies).

\section{Leptospirosis}

Five studies carried out on leptospirosis assessed the performance of commercial and in-house rapid tests. Dip-S-Tick (PanBio InDx, Inc., Baltimore, MD, USA) and LeptoTek Dri Dot (bioMérieux) showed sensitivities from 32.9 to $72.3 \%$ and $50 \%$ to $80 \%$ in acute phase, respectively, which increased to $80 \%$ and $84 \%$ in convalescent samples, respectively. Specificity was high for both tests (>95\%) [172]. LeptoTek Lateral Flow (Organon Teknika Ltd., Ireland) showed sensitivities of $65.4 \%$ in acute samples and $80.9 \%$ in samples at a later stage with $93.6 \%$ specificity [173]. LEPTO dipstick was highly sensitive (93.3\%) but poorly specific (25\%) in a study in Venezuela [174] while in Cuba, it was reported that LeptoTek Lateral Flow and LeptoTek Dip Stick were implemented for rapid disease confirmation with sensitivities and specificities $>90 \%$, and LeptoTek Dri Dot for the investigation of suspected cases. Lepto Cuba (Cuban latex test) had results comparable to the latter [175]. A novel in-house method yielded sensitivities similar to IgM ELISA in Brazil with lower specificity [176]. (Additional file 3: Table S2: Details of included studies).

\section{Filariasis}

Five studies on filariasis assessed performance or acceptability of rapid tests. They reported excellent agreement, with kappa value of 0.825 (95\% CI: 0.739-0.912) between BinaxNOW ${ }^{\bullet}$ Filariasis card tests and Filariasis Test Strips (FTS) (both from Alere Scarborough, Inc., Scarborough, ME, USA). They also reported problems with the study personnel's handling of FTS tests and the fact that $1.7 \%$ of tests turned positive at $30 \mathrm{~min}$ and $3.8 \%$ at $12 \mathrm{~h}$, with potential for false positive results [177]. An in-house Brugia Rapid dipstick showed 87\% (95\% CI: 66.4-97.2) sensitivity and $100 \%$ specificity, and was regarded by field staff as easy to use and useful for increasing drug compliance, as subjects could visualize results on their own [178]. A commercial test, Brugia Rapid ${ }^{\circ}$ (Reszon Diagnostics International, Subang Java, Selangor, Malaysia) was compared to microfilaremia in two endemic areas and one non-endemic area, showing $1 \%, 15 \%$, and $5 \%$ positivity by rapid test against a single participant (out of 1543 tested) positive for microfilaremia, respectively. At one of the study sites, $4 \%$ of results were invalid [179]. The two theses from Brazil assessed the ICT card test, with overall sensitivities of $94.4 \%$ and $100 \%$ and specificities of $90.7 \%$ and $84.4 \%$ [180, 181]. (Additional file 3: Table S2: Details of included studies). 


\section{Enteric fever}

For enteric fever, there were three studies: two assessed the performance of Tubex ${ }^{\oplus}$ (IDL Biotech, Borlange, Sweden) in febrile subjects and one assessed Diazo reagent. Using a Tubex score of $\geq 4$ as a cut-off for positivity, the sensitivity was 69\% and specificity, 95\% in China and 56\% (95\% CI: 47-66) and 88\% (95\% CI: 82-94), respectively, in India, $[182,183]$. The study from Nigeria found that the Diazo reagent had $27.3 \%$ sensitivity when compared to the Widal test [184]. (Additional file 3: Table S2: Details of included studies).

\section{Schistosomiasis}

Three studies on schistosomiasis evaluated circulating cathodic antigen (CCA) immunochromatographic tests (Rapid Medical Diagnostics, Pretoria, South Africa) and an in-house IgG rapid diagnostic test in urine samples. In Uganda, two versions of CCA, the second believed to be less sensitive than the first, were compared to two, four or six Kato-Katz smears, resulting in overall CCA1/CCA2 sensitivities of $91 \% / 70 \%, 89 \% / 63 \%$, and $88 \% / 59 \%$, and CCA1/CCA2 specificities of $47 \% / 86 \%, 50 \% / 90 \%$, and $52 \% / 91 \%$, respectively [185]. In Brazil, CCA against two Kato-Katz tests was $85.4 \%$ (95\% CI: 72.2-93.9) sensitive and $78 \%$ (95\% CI: 62.4-89.4\%) specific [186]. The rapid test for IgG evaluated in Kenya had 97\% (95\% CI: 91-100) sensitivity and 78\% (95\% CI: 67-89\%) specificity [187]. (Additional file 3: Table S2: Details of included studies).

\section{Dengue}

Two studies on dengue assessed the performance of rapid tests and the knowledge of diagnostic procedures among primary care personnel, respectively. In Taiwan, China, the SD BIOLINE Dengue DUO ${ }^{\circ}$ rapid immunochromatographic test kit (Standard Diagnostics, Inc., Gyeonggi-do, Republic of Korea), interpreted as positive when either NS1 or IgM were positive, yielded sensitivities above $90 \%$ from day 0 to day 5 and specificities between 14.29 and $74.6 \%$ in the same period in the context of a DENV2 epidemic [188]. In Saudi Arabia, primary care physicians' self-reported knowledge of about dengue was found to be excellent among $43.4 \%$ of participants, but with poor use of specific dengue diagnostics, partly due to their unavailability [189]. (Additional file 3: Table S2: Details of included studies).

\section{Leprosy}

Two studies reported on leprosy assessed the impact and performance of the ML Flow rapid test, and one reported the acceptability of a "representative lateral flow-based rapid test." A greater decrease in multibacillary cases was observed in health services in Brazil that participated in the ML Flow study (from $73.1 \%$ in 2000 to $53.3 \%$ in 2004) compared to non-participating services (from 80.6 to
$72.2 \%$ in the same period). Agreement of rapid test with final classification given by the health centre for treatment purposes was substantial (kappa 0.77) [190]. In the Philippines, $95.9 \%$ of patients, $93.2 \%$ of household contacts, and $81.4 \%$ of community contacts thought rapid tests would be beneficial, with $88.6 \%$ of patients willing to "definitely" submit to testing, followed by $69.4 \%$ of households and $72.2 \%$ of community contacts [191]. (Additional file 3: Table S2: Details of included studies).

\section{Chagas disease}

One study assessed the Chagas Detect Plus rapid test (InBios, Seattle, WA, USA) against conventional serology, with sensitivities of $96.2 \%$ in whole blood and $99.3 \%$ in serum and specificities of $98.8 \%$ in whole blood and $96.9 \%$ in serum [192]. (Additional file 3: Table S2: Details of included studies).

\section{Human African trypanosomiasis}

One conference abstract reported kappa 0.27 (95\% CI: 0.24-0.3) between rapid test SD BIOLINE ${ }^{\circledR}$ HAT (Standard Diagnostics Inc., Gyeonggi-do, Republic of Korea) and Card Agglutination Test for Trypanosomiasis (CATT) during routine screening [193]. (Additional file 3: Table S2: Details of included studies).

\section{Cholera}

There was one study on cholera that showed $91.7 \%$ sensitivity and $72.9 \%$ specificity of the Crystal VC kit (Span Diagnostics, Surat, India) against culture in diluted stool samples from hospitalized subjects [194]. (Additional file 3: Table S2: Details of included studies).

\section{Discussion}

We sought to identify which rapid diagnostic tests for VBDs and other infectious diseases of poverty in urban areas have been evaluated in the field and what were the evaluation results. The present study showed that rapid diagnostic tests are being used in urban areas, but that reporting on the field evaluation of these type of tests is dominated, by a large margin, by studies on malaria and tuberculosis. This could be attributed partially to the burden of disease, the availability of devices to be tested, and the research priorities of funding agencies. Fewer studies were found on neglected tropical diseases (visceral leishmaniasis, filariasis, leptospirosis, enteric fever, schistosomiasis, dengue, leprosy, Chagas disease, human African trypanosomiasis, and cholera), supporting the need to further improve research and product development, including rapid diagnostics, in these groups of diseases. The lack of studies on the other diseases included in our search strategy (viral encephalitis, viral haemorrhagic fevers, echinococcosis, rickettsial diseases, onchocerciasis, and trachoma) might reflect the even 
lower investment in diagnostic development for these diseases, the lack of a perceived need for rapid diagnostic tests in the urban context, or limitations of our search strategy. The search identified both commercial and in-house tests, showing the potential for product development outside the industry that could be further explored, particularly for neglected tropical diseases.

Performance is, logically, a key characteristic of diagnostic tests to be prioritized for field evaluation and, hence, at least one field performance evaluation per disease was identified. In malaria, a relatively large number of rapid tests are available on the market; hence, there is a greater need for regulation and quality assurance in this area. We identified studies that compared the performance of several commercial tests simultaneously. Results from this type of study would be useful to providers faced with having to choose from among several rapid diagnostics options. The advantages and disadvantages of such studies have been highlighted [195]. Performance studies were carried out in several countries on several continents, but local studies of malaria rapid diagnostics may be required, since the results from one region cannot necessarily be extrapolated to another, as shown by a systematic review [196]. Continent was identified as a source of heterogeneity in test performance, with lower sensitivity and specificity in Africa than in Asia, and high specificity and low sensitivity in South America. Heterogeneity within the same continent was not assessed, and this systematic review included only $P$. falciparum malaria [196]. A separate systematic review analyzed the performance of rapid tests for non-falciparum malaria [197]. The separate analysis by falciparum and non-falciparum malaria does not necessarily reflect the performance of the diagnostics under field conditions where several species co-exist. Therefore, the field performance of tests could be further affected by the prevalence of Plasmodia over time and other factors not analyzed, such as whether the rapid tests are used in the hospital or community context. Despite the few studies identified in our review, there was a systematic review of rapid diagnosis of malaria in pregnancy that included a relatively large number of studies from Africa, but not enough to compare performance between rapid tests or parasite species [198].

For tuberculosis, most studies evaluated the performance of Xpert ${ }^{\circ}$ MTB/RIF with heterogeneous results, but the sources of heterogeneity were clearer compared to malaria rapid tests. Decreased sensitivity in respiratory samples was reported in smear negative cases and HIV-infected cases, as confirmed by a systematic review [199]. Other sources of heterogeneity identified by meta-regression were number of samples, incidence of TB in the samples, quality of reporting, and proportion of smear-positive samples [200]. For non-respiratory samples, reported sensitivities of $>75 \%$ were similar to the findings of a systematic review [200]. Likewise, the low sensitivity of TB-LAM found was confirmed in a systematic review [201]. Detection of tuberculosis human antibodies by immunochromatography, such as ICT, On-site TBIgG/IgM, TB STAT PAK ${ }^{\circ}$, and PRIM, yielded variable sensitivity and specificity; as such, this would appear to be an interesting potential topic for a systematic review.

Our search retrieved relatively few studies on visceral leishmaniasis, dengue, schistosomiasis, leprosy, enteric fever, Chagas disease, and human African trypanosomiasis, even though at least one systematic review of diagnostics for each of these diseases has been previously published. In visceral leishmaniasis, most studies were conducted with rK39 as the target, although other rapid tests with other targets have been developed. A recent systematic review of only rK39-based tests suggests that rapid tests or ELISA are good choices for implementation [202]. The fact that our search was restricted to field evaluations might explain the relatively small number of studies on this disease. It is to be expected that more field evaluations and implementation studies will be performed in the future to confirm some preliminary findings pointing towards not differences in performance between various rK39 available tests and the presence of heterogeneity between East Africa and the Indian subcontinent [203]. A similar explanation of search being restricted to field evaluation could be provided for the other diseases. In dengue, IgM and NS1-based tests have been addressed in systematic reviews separately, with variable sensitivities and identified sources of heterogeneity; however, results suggest that simultaneous detection of both markers would improve their performance, and hence more studies in the future to assess the combination of tests would be useful $[204,205]$. In schistosomiasis, we observed the effect of the gold standard used. A systematic review summarized the challenges of assessing the performance of schistosomiasis diagnostics that could be more sensitive than the commonly used reference test (Kato-Katz smear) [206]. In leprosy, the ML Flow rapid test that detects IgM to specific phenolic glycolipid-I (PGL-I) is used to improve the classification of multibacillary cases and hence to assist in clinical diagnosis, but not as a stand-alone diagnostic test [207]. The performance of rapid tests for enteric fever does not support their routine use, at least not by themselves, but potentially in combination with other tests [208]. While the rapid test for Chagas disease was highly sensitive and specific, the performance of the rapid test for human African trypanosomiasis was disappointing. For Chagas disease and human African trypanosomiasis, the available systematic reviews do not include the identified rapid tests we found in this search $[209,210]$. A systematic review of rapid tests for Chagas disease could provide the evidence required to inform decisions. This is also true for filariasis and leptospirosis, which showed contrasting results in the performance of the available rapid tests. 
The impacts and implementation outcomes of rapid tests-mainly acceptability and cost, followed by adoption, feasibility, and sustainability-are being evaluated. These studies shed light on both the facilitators and the challenges encountered when using rapid diagnostics under real-life conditions, ranging from cultural to technical and administrative issues. The reported reduction in antimalarial drugs use as a result of the implementation of rapid tests is consistent with a systematic review of controlled trials in rural endemic areas that also found the impact of malaria rapid tests to be directly correlated with provider compliance [211], which in turn depends on other factors [212]. Interestingly, the impact of Xpert ${ }^{\circ}$ MTB/RIF in improving TB case detection does not necessarily imply the withdrawal of other diagnostic methods (e.g. smear microscopy), but rather their more selective use. The implementation outcomes results observed in the present study help to inform on what other contextual factors (cultural, political, socioeconomic, health system, institutional) should be taken into account. Some of these are: community beliefs related to the sample or specimen (blood, sputum, urine, etc.); trust in the accuracy of the test; ability to discern the target of the test (e.g. patients believing they are being tested for HIV and not for malaria); burden of work to providers; sustainability of supplies; training issues; and routine quality assessment. Table 3 summarizes the identified knowledge gaps and priority needs for future research.

\section{Strengths and limitations of this review}

To widen the coverage of potential relevant studies, the search strategy included documents in four languages (English, Spanish, French, and Portuguese) and a comprehensive list of infectious diseases. In fact, a substantial number of titles and abstracts were retrieved. The aim of this scoping review was to describe the tests and results of field evaluations of rapid diagnostics and not to be exhaustive. We believe the use of a key concept representing "urban area" resulted in decreased sensitivity, since information on whether the study was conducted in an urban area is not systematically reported or compulsorily requested for publication. For this same reason, we cannot rule out the misclassification of included studies as urban. Hence, we suggest conducting

Table 3 Knowledge gaps and priority needs for future research

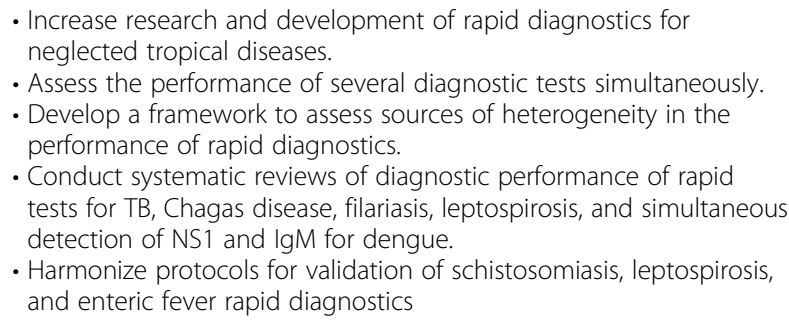

future scoping reviews without a term for urban area, to increase sensitivity, but restricting them to a smaller list of diseases to keep the reviews feasible. The extraction process revealed there was not enough information on who performed the rapid tests. This points to the need to improve the reporting of diagnostic studies. QUADAS 2 was not used to analyze the quality of the studies, as we used a standardized extraction grid for this series of scoping reviews [213]. We suggest considering the inclusion of implementation outcomes in the standardized reporting guidelines of diagnostic studies.

\section{Implications for public health policy and/or practice}

Rapid diagnostic tests for VBDs and other diseases of poverty are being used in the urban context with demonstrated positive impacts on case detection, rational use of drugs, and even decreased mortality. Nevertheless, most evidence comes from malaria rapid tests, where there are multiple options whose performance is heterogeneous. Decision-makers are advised to consider the potential sources of heterogeneity in the performance of diagnostic tests when deciding whether to implement them in their own context; these include geographical region, patients' characteristics (e.g. HIV status, pregnancy), and providers' level of expertise. Nonetheless, in some situations, it is neither easy nor feasible to wait for the evidence expected from required multicountry studies; in such cases, the recommended strategy would be to analyze the availability, costs, and prior results of rapid diagnostics within the country or in comparable geographical regions to inform decisions. When faced with multiple options for rapid diagnostics, or with lack of data, comparative operational research might be needed to verify whether those rapid diagnostics work under routine conditions and are acceptable to providers and patients, as well as to confirm their implementation feasibility in representative contexts before rolling them out.

This review highlights that, for practitioners and public health workers, besides issues of performance and sources of heterogeneity, when implementing rapid diagnostics it is essential to take into account the beliefs of communities and providers, their trust in the accuracy of the tests, the burden of work to providers, the sustainability of supply chains, training issues, and quality assurance, among other factors. Hence, pragmatic research is recommended to assess acceptability, feasibility, cost, and sustainability in representative contexts. Monitoring impacts, cost-effectiveness, correct use, quality, and long term sustainability is necessary to fully justify the decision to implement and maintain the investment in rapid diagnostics. Table 4 summarizes the implications for public health policy and practice. 
Table 4 Implications for public health policy and practice

- Take context into account when deciding on the use of rapid diagnostics, as performance, impact, and implementation outcomes are highly variable.

- Consider the beliefs of communities and providers before implementing rapid diagnostics

- Confirm that rapid diagnostics are feasible to implement in representative contexts before rolling out.

- Burden of work to providers, sustainability of supplies, training, and routine quality assessment are key factors to be considered before implementation.

- Invest in pragmatic evaluation before, during, and after implementation.

\section{Conclusions}

The present scoping review provides an overview of the field validation and implementation studies of rapid diagnostic tests for VBD and other infectious diseases of poverty in urban areas. We identified a relatively large number of available malaria rapid diagnostic tests that have been evaluated and fewer options for other diseases, such as visceral leishmaniasis, dengue, Chagas disease, leptospirosis, filariasis, and leprosy. The field performance of malaria rapid diagnostics depends upon epidemiological, technical and clinical factors. There is evidence of their positive impact in decreased use of presumptive treatment but challenges remain to achieve their successful implementation. Based on their reported good performance, Xpert $\mathrm{MTB} /$ RIF for tuberculosis and rapid diagnostics for visceral leishmaniasis that detect rK39 warrant more implementation studies. Multicentre studies and/or systematic reviews of rapid diagnostics for dengue using simultaneous detection of both NS1 and IgM, as well as for Chagas disease, filariasis, and leptospirosis, are required to provide evidence on their performance and hence, suitability of further implementation studies.

There is a need to establish valid reference standards to evaluate the performance of rapid diagnostic tests, particularly for schistosomiasis, and harmonised field validation research protocols to take into account potential sources of heterogeneity such as geographical region, assay, HIV co-infection, infection type and load, and epidemiological characteristics. This is likely to demand a global (multicountry or multicontinent) approach to field validation of rapid diagnostic tests. Implementation studies that assess rapid diagnostics as part of complex interventions rather than by themselves are likely to be required to identify solutions to some of the challenges encountered in their implementation in real-life situations.

\section{Additional files}

Additional file 1: Multilingual abstracts in the six official working languages of the United Nations. (PDF $484 \mathrm{~kb}$ )

Additional file 2: Table S1. Search strategy. (DOC $222 \mathrm{~kb}$ )

Additional file 3: Table S2. Details of included studies. (DOCX 234 kb)

\section{Abbreviations}

ASTAIRE: Analysis of the transferability of health promotion interventions: ELISA: Enzyme-linked immunosorbent assay; MMAT: Mixed methods appraisal tool; TDR: The special programme for research and training in tropical diseases; TIDieR: Template for intervention description and replication; VBDs: Vector-borne diseases; WHO: World Health Organization

\section{Acknowledgements}

We thank Laura Aguirre for their assistance in finding full texts of documents and their feedback on the extraction grid. We thank Donna Riley for proofreading the entire manuscript.

\section{Funding}

This study was funded by WHO/TDR Special program for Research and Training in Tropical Diseases and by Universidad del Valle, Cali-Colombia.

\section{Availability of data and materials}

The datasets analysed during the current study are available from the corresponding author on reasonable request.

\section{Authors' contributions}

All authors participated in formulating the search strategy and identifying relevant studies. LO, JAG, LGP, VG, LT conducted data extraction and reviewed the results. SD and VR validated the entire process. LO, JAG and LGP wrote the first draft of manuscript and all authors critically reviewed and approved the final version.

Ethics approval and consent to participate Not applicable.

\section{Consent for publication}

Not applicable.

\section{Competing interests}

The authors declare that they have no competing interests.

\section{Author details}

${ }^{1}$ Epidemiology and Population Health Research Group, School of Public Health, Universidad del Valle, Calle 4B No. 36-00 Edif 118 Escuela de Salud Pública, Universidad del Valle Campus San Fernando, Cali, Colombia. ${ }^{2}$ School of Medicine, Universidad del Valle, Cali, Colombia. ${ }^{3}$ University of Montreal Public Health Research Institute (IRSPUM), Montreal, Canada. ${ }^{4}$ French Institute for Research on Sustainable Development (IRD), Paris Descartes University, Population and Development Center (CEPED), Université Paris Sorbonne Cité, National Institute of Health and Medical Research (INSERM), Health, Vulnerabilities and Gender Relations South (SAGESUD), Paris, France.

Received: 9 February 2018 Accepted: 1 August 2018

Published online: 03 September 2018

\section{References}

1. Bissonnette $L$, Bergeron MG. Diagnosing infections--current and anticipated technologies for point-of-care diagnostics and home-based testing. Clin Microbiol Infect. 2010;16:1044-53. Available from: https://www.ncbi.nlm.nih. gov/pubmed/20670286

2. Mabey D, Peeling RW, Ustianowski A, Perkins MD. Diagnostics for the developing world. Nat Rev Microbiol. 2004;2:231-40. Available from: https:// www.ncbi.nlm.nih.gov/pubmed/15083158

3. Peeling RW, Mabey D. Point-of-care tests for diagnosing infections in the developing world. Clin Microbiol Infect. 2010;16:1062-9. Available from: https://www.ncbi.nlm.nih.gov/pubmed/20670288

4. Alirol E, Getaz L, Stoll B, Chappuis F, Loutan L. Urbanisation and infectious diseases in a globalised world. Lancet Infect Dis. 2011;11:131-41. Available from: http://www.ncbi.nlm.nih.gov/pubmed/21272793

5. Arksey H, O'Malley L. Scoping studies: towards a methodological framework Int J Soc Res Methodol. 2005;8:19-32. Available from: http://www.tandfonli ne.com/doi/abs/10.1080/1364557032000119616

6. World Health Organization. Prequalification of in vitro diagnostics. Geneva: World Health Organization; 2016. Available from: http://www.who.int/diagn ostics_laboratory/evaluations/en/. 
7. Special Programme for Research and Training in Tropical Diseases TDR. Diagnostics research. Geneva: World Health Organization; 2016. Available from: http://www.who.int/tdr/publications/topics/diagnostics/en/

8. VonVille H. LibGuides: Excel Workbooks for Systematic Reviews \& Corresponding Handouts: Excel Workbooks for SRs: University of Texas School of Public Health; 2017. Available from: http://hsls.libguides.com/ APHA_SR_Learning_Institute/SR_tools.

9. World Health Organization. Simple / rapid tests. Geneva: World Health Organization; 2014. Available from: http://www.who.int/diagnostics_laborato ry/faq/simple_rapid_tests/en/

10. World Health Organization. WHO endorses new rapid tuberculosis test. Press release 8 December 2010. Geneva: World Health Organization; 2012. Available from: http://www.who.int/tb/features_archive/new_rapid_test/en/

11. United Nations. Principles and recommendations for population and housing censuses, revision 3. New York: United Nations Department of Economic and Social Affairs; 2015. Available from: https://unstats.un.org/ unsd/demographic/meetings/egm/NewYork/2014/P\&R_Revision3.pdf

12. Pluye $P$, Robers $E$, Cargo M, Bartlett $G, O^{\prime}$ Cathain A, Griffiths F, et al. Proposal: a mixed methods appraisal tool for systematic mixed studies reviews. Montreal: Department of Family Medicine, McGill University; 2011. Available from: http://mixedmethodsappraisaltoolpublic.pbworks.com/w/ page/24607821/FrontPage

13. Hoffmann TC, Glasziou PP, Boutron I, Milne R, Perera R, Moher D, et al. Better reporting of interventions: template for intervention description and replication (TIDieR) checklist and guide. BMJ. 2014;348:g1687. Available from: https://www.ncbi.nlm.nih.gov/pubmed/24609605

14. Cambon L, Minary L, Ridde V, Alla F. A tool to facilitate transferability of health promotion interventions: ASTAIRE. Sante Publique. 2014;26:783-6. Available from: https://www.ncbi.nlm.nih.gov/pubmed/25629672

15. Proctor $E$, Silmere $H$, Raghavan $R$, Hovmand $P$, Aarons $G$, Bunger $A$, et al. Outcomes for implementation research: conceptual distinctions, measurement challenges, and research agenda. Adm Policy Ment Health. 2011;38:65-76. Available from: https://www.ncbi.nlm.nih.gov/pubmed/20957426

16. Gitonga CW, Kihara JH, Njenga SM, Awuondo K, Noor AM, Snow RW, et al. Use of rapid diagnostic tests in malaria school surveys in Kenya: does their under-performance matter for planning malaria control? Am J Trop Med Hyg. 2012;87:1004-11. Available from: https://www.ncbi.nlm.nih.gov/pmc/ articles/PMC3516067/

17. Tarimo DS, Jani B, Killewo JZ. Management of fever among under-fives and utility of malaria rapid diagnostic test under reduced malaria burden in Rufiji District, southeastern Tanzania. Asian Pacific J Trop Dis. 2015;5:862868. Available from: http://www.embase.com/search/results? subaction = viewrecord\&from=export\&id=L608698921.

18. Tobing HL, Syukur S, Purwati E, Zein R, Muzahar, Gani EH, et al. Comparison of SD bioline malaria ag-pf/pan test with microscopic examination for detection of P. Falciparum, P. Vivax and mixed infection in south Nias, north Sumatera, Indonesia. Res J Pharm Biol Chem Sci. 2015;6:917-924. Available from: http://www.embase.com/search/results?subaction = viewrecord\&from $=$ export\&id $=\mathrm{L} 605530159$.

19. Ngasala BE. Performance of three CareStartTM malaria rapid diagnostic tests after reduction in malaria prevalence in Bagamoyo, Tanzania. Am J Trop Med Hyg. 2014;91:80.

20. Laban NM, Kobayashi T, Sullivan D, Shiff CJ, Moss WJ. Comparison of Pfhrp2based RDTs and PCR in an area of declining malaria transmission in southern Zambia. Am J Trop Med Hyg. 2014;91:110-1.

21. Samadoulougou S, Kirakoya-Samadoulougou F, Sarrassat S, Tinto H, Bakiono F, Nebié I, et al. Paracheck ${ }^{\circledast}$ rapid diagnostic test for detecting malaria infection in under five children: A population-based survey in Burkina Faso. Malar J. 2014;13 Available from: https://www.ncbi.nlm.nih.gov/pmc/articles/ PMC3995324/.

22. Grigg MJ, William T, Barber BE, Parameswaran U, Bird E, Piera K, et al. Combining parasite lactate dehydrogenase-based and histidine-rich protein 2-based rapid tests to improve specificity for diagnosis of malaria due to Plasmodium knowlesi and other Plasmodium species in Sabah, Malaysia. J Clin Microbiol. 2014;52:2053-60.

23. Mbonye AK, Magnussen P, Lal S, Hansen KS, Cundill B, Chandler C, et al. A cluster randomised trial introducing rapid diagnostic tests into registered drug shops in Uganda: impact on appropriate treatment of malaria. PLoS One. 2015;10:e0129545

24. Nombe G, Mavoko HM, Maketa V, Matangila J, Kalabuanga M, Luz RD, et al. Accuracy of the malaria rapid diagnostic test SD bioline ${ }^{\circledast}$ in symptomatic children versus non symptomatic. Trop Med Int Heal. 2013;18:157-158. Available from: http://www.embase.com/search/results?subaction = viewrecord\&from=export\&id=L71540358.

25. Metzger WG, Giron AM, Vivas-Martinez S, Gonzalez J, Charrasco AJ, Mordmuller BG, et al. A rapid malaria appraisal in the Venezuelan Amazon. Malar J. 2009:8:291.

26. Mendoza NM, Garcia M, Cortes LJ, Vela C, Erazo R, Perez P, et al. Evaluation of two rapid diagnostic tests, NOW ICT malaria pf/Pv and OptiMAL, for diagnosis of malaria. Biomedica. 2007;27:571-80.

27. Klarkowski D, Sutamihardja A, Chiduo S, Sekonde E, Hamm T, Ohrt C, et al. Baseline assessments on the use of malaria rapid diagnostic tests (MRDT) in hospitals and dispensaries in Tanzania. Am J Trop Med Hyg. 2012;87:256.

28. Kapito-Tembo A, Mathanga D, Fiore J, Seydel K, Liomba M, Bauleni A, et al. Rapid diagnostic test performance in the setting of differing transmission intensities: the Malawi ICEMR experience. Am J Trop Med Hyg. 2012;87:259.

29. Phommasone K, Adhikari B, Henriques G, Pongvongsa T, Phongmany P, von Seidlein $L$, et al. Asymptomatic Plasmodium infections in 18 villages of southern Savannakhet Province, Lao PDR (Laos). Malar J. 2016;15:296.

30. Alareqi LMQ, Mahdy MAK, Lau Y-L, Fong M-Y, Abdul-Ghani R, Ali AA, et al. Field evaluation of a PfHRP-2/pLDH rapid diagnostic test and light microscopy for diagnosis and screening of falciparum malaria during the peak seasonal transmission in an endemic area in Yemen. Malar J. 2016;15:49.

31. Nankabirwa Jl, Yeka A, Arinaitwe E, Kigozi R, Drakeley C, Kamya MR, et al. Estimating malaria parasite prevalence from community surveys in Uganda: a comparison of microscopy, rapid diagnostic tests and polymerase chain reaction. Malar J. 2015;14:528.

32. Larsen DA, Chisha Z, Winters B, Mwanza M, Kamuliwo M, Mbwili C, et al. Malaria surveillance in low-transmission areas of Zambia using reactive case detection. Malar J. 2015;14:465.

33. Turki H, Raeisi A, Malekzadeh K, Ghanbarnejad A, Zoghi S, Yeryan M, et al. Efficiency of nested-PCR in detecting asymptomatic cases toward malaria elimination program in an endemic area of Iran. Iran J Parasitol. 2015;10:39-45.

34. Hashizume M, Kondo H, Murakami T, Kodama M, Nakahara S, Lucas MES, et al. Use of rapid diagnostic tests for malaria in an emergency situation after the flood disaster in Mozambique. Public Health. 2006; 120:444-7.

35. Muhindo HM, llombe G, Meya R, Mitashi PM, Kutekemeni A, Gasigwa D, et al. Accuracy of malaria rapid diagnosis test Optimal-IT((R)) in Kinshasa, the Democratic Republic of Congo. Malar J. 2012;11:224.

36. Kahama-Maro J, D'Acremont V, Mtasiwa D, Genton B, Lengeler C. Low quality of routine microscopy for malaria at different levels of the health system in Dar Es Salaam. Malar J. 2011;10:332.

37. Hassanpour GR, Keshavarz H, Mohebali M, Zeraati H, Azizi E, Raiisi A. Detection of malaria infection in blood transfusion: a comparative study among real-time PCR, rapid diagnostic test and microscopy. Clin Microbiol Infect. 2011;17:S397.

38. Houmsou RS, Amuta EU, Sar T, Adagba AH. Malarial infection among patients attending a Nigerian semi-urban based hospital and performance of HRP-2 pf Rapid diagnostic Test (RDT) in screening clinical cases of Plasmodium falciparum malaria. Transl Biomed. 2011;2 Available from: http:// www.transbiomedicine.com/translational-biomedicine/malarial-infectionamong-patients-attending-a-nigerian-semiurban-based-hospital-andperformance-of-hrp2-pf-rapid-diagnostic-test-rdt-in-screening-clinical-casesof-plasmodium-falciparum-malaria.php?aid=2554.

39. Dolo A, Diallo M, Saye R, Konare A, Ouattara A, Poudiougo B, et al. Obstacles to laboratory diagnosis of malaria in Mali--perspectives. Med Trop (Mars). 2010;70:158-62.

40. Andrade BB, Reis-Filho A, Barros AM, Souza-Neto SM, Nogueira LL, Fukutani $\mathrm{KF}$, et al. Towards a precise test for malaria diagnosis in the Brazilian Amazon: comparison among field microscopy, a rapid diagnostic test, nested PCR, and a computational expert system based on artificial neural networks. Malar J. 2010;9:117.

41. Satyasi S, Poosapati R. A study of evaluation of rapid diagnostic techniques of malaria in urban slums of Vijayawada, Krishna District, Andhra Pradesh, India. Res J Pharm Biol Chem Sci. 2014;5:1428-1449. Available from: http:// www.embase.com/search/results?subaction = viewrecord\&from=export\&id= L373601701.

42. Sayang C, Soula G, Tahar R, Basco LK, Gazin P, Moyou-Somo R, et al. Use of a histidine-rich protein 2-based rapid diagnostic test for malaria by health personnel during routine consultation of febrile outpatients in a peripheral health facility in Yaounde, Cameroon. Am J Trop Med Hyg. 2009:81:343-7. 
43. Kamugisha ML, Msangeni H, Beale E, Malecela EK, Akida J, Ishengoma DR, et al. Paracheck pf compared with microscopy for diagnosis of Plasmodium falciparum malaria among children in Tanga City, North-Eastern Tanzania. Tanzan J Health Res. 2008;10:14-9. Available from: https://www.scopus.com/ inward/record.uri?eid=2-s2.0-58149115536\&partnerlD=40\&md5=e8e7703e28 e569bf5a665cbbcb4c804f

44. Arcanjo ARL, De Lacerda MVG, Alecrim WD, Alecrim MDGC. Evaluation of the Optimal-IT ${ }^{\oplus}$ and ICT P.f./P.V. ${ }^{\circledR}$ rapid dipstick tests for diagnosing malaria within primary healthcare in the municipality of Manaus, Amazonas. Rev Soc Bras Med Trop. 2007:40:88-90.

45. Kyabayinze DJ, Zongo I, Cunningham J, Gatton M, Angutoko P, Ategeka J, et al. HRP2 and pLDH-based rapid diagnostic tests, expert microscopy, and PCR for detection of malaria infection during pregnancy and at delivery in areas of varied transmission: A prospective cohort study in Burkina Faso and Uganda. PLoS One. 2016;11 Available from: http://journals.plos.org/plosone/ article?id=10.1371/journal.pone.0156954.

46. Singh N, Valecha N, Nagpal AC, Mishra SS, Varma HS, Subbarao SK. The hospital- and field-based performances of the OptiMAL test, for malaria diagnosis and treatment monitoring in Central India. Ann Trop Med Parasitol. 2003;97:5-13.

47. Grobusch MP, Hanscheid T, Gobels K, Slevogt H, Zoller T, Rogler G, et al. Comparison of three antigen detection tests for diagnosis and follow-up of falciparum malaria in travellers returning to Berlin, Germany. Parasitol Res. 2003:89:354-7.

48. Ferro BE, Gonzalez IJ, de Carvajal F, Palma GI, Saravia NG. Performance of OptiMAL(R) in the diagnosis of Plasmodium vivax and Plasmodium falciparum infections in a malaria referral center in Colombia. Mem Inst Oswaldo Cruz. 2002;97:731-5.

49. Mwanziva C, Manjurano A, Mbugi E, Mweya C, Mkali H, Kivuyo MP, et al. Defining malaria burden from morbidity and mortality records, self treatment practices and serological data in Magugu, Babati District, northern Tanzania. Tanzan J Health Res. 2011;13(2):97-105.

50. Osei-Yeboah J, Kwame Norgbe G, Yao Lokpo S, Khadijah Kinansua M, Nettey L, Allotey EA. Comparative performance evaluation of routine malaria diagnosis at Ho Municipal Hospital. J Parasitol Res. 2016;2016. Available from: https://www.ncbi.n/m.nih.gov/pmc/articles/PMC5055952/.

51. Sutherland $\sqcup$, Bustinduy AL, Mungai PL, Muchiri EM, Kitron U, Zimmerman PA, et al. Performance of a rapid diagnostic card test for detection of singleor multi-species Plasmodium infections among residents of southern Coast Province, Kenya. Am J Trop Med Hyg. 2011;85:415.

52. Diallo A, Dos Santos S, Diop A, Barbosa L, Le Hesran JY. Urban malaria in Dakar: rapid diagnostic test implementation and presumptive diagnosis. Am J Epidemiol. 2011;173:S26.

53. Ntoumi F, Vouvoungui JC, Ibara R, Landry M, Sidibé A. Malaria burden and case management in the republic of Congo: limited use and application of rapid diagnostic tests results. BMC Public Health. 2013;13. Available from: https://bmcpublichealth.biomedcentral.com/articles/10.1186/1471-2458-13135.

54. Lee PW, Ji DD, Liu CT, Rampao HS, Do Rosario VE, Lin IF, et al. Application of loop-mediated isothermal amplification for malaria diagnosis during a follow-up study in São Tomé. Malar J. 2012;11 Available from: https://www. scopus.com/inward/record.uri?eid=2-s2.0-84870415537\&partnerlD=40\&md5 $=7 f 1 e 4 b 503 f 71669113 e d 42420126 f 51 d$

55. Binesh Lal Y, Jayakumar S, Kalyani M, Mathew R, Shameem Banu AS, Dhinesh R. Correlation of quantitative Buffy coat, blood smear and antigen detection in diagnosing malarial infection. J Clin Diagnostic Res. 2011;5:961-3.

56. Metzger WG, Vivas-Martínez S, Giron A, Vaccari E, Campos E, Rodríguez I, et al. Assessment of routine malaria diagnosis in the Venezuelan Amazon. Trans R Soc Trop Med Hyg. 2011;105:262-8. Available from: https://www. scopus.com/inward/record.uri?eid=2-s2.0-79955001664\&partnerlD=40\&md5 $=74212356 \mathrm{c} 577 f 5328 \mathrm{ab} 83 \mathrm{c} 2 \mathrm{dfc} 13 \mathrm{fe} 5 \mathrm{f}$

57. Sousa-Figueiredo JC, Oguttu D, Adriko M, Besigye F, Nankasi A, Arinaitwe M, et al. Investigating portable fluorescent microscopy (CyScope $\left.{ }^{\oplus}\right)$ as an alternative rapid diagnostic test for malaria in children and women of childbearing age. Malar J. 2010;9 Available from: https://www.scopus.com/ inward/record.uri?eid=2-s2.0-77955957368\&partnerlD=40\&md5=8128fa5e15 b0da75f87a190b1ae2972d

58. A-Elgayoum SME, El-Feki AEKA, Mahgoub BA, El-Rayah EA, Giha HA. Malaria overdiagnosis and burden of malaria misdiagnosis in the suburbs of Central Sudan: special emphasis on artemisinin-based combination therapy era. Diagn Microbiol Infect Dis. 2009;64:20-6. Available from: https://www.scopus.com/
inward/record.uri?eid=2-s2.0-65649137682\&partnerID=40\&md5=83b4f6634c31 $5 f 8 d a 5 d 76 c 9 a c 409038 f$

59. Chanda P, Castillo-Riquelme M, Masiye F. Cost-effectiveness analysis of the available strategies for diagnosing malaria in outpatient clinics in Zambia. Cost Eff Resour Alloc. 2009;7 Available from: https://www.scopus.com/ inward/record. uri?eid=2-s2.0-65749093233\&partnerlD=40\&md5=5eb52bb3d0 fb0ae010de42ce379b3141

60. Harvey SA, Jennings L, Chinyama M, Masaninga F, Mulholland K, Bell DR. Improving community health worker use of malaria rapid diagnostic tests in Zambia: package instructions, job aid and job aid-plus-training. Malar J. 2008;7 Available from: https://www.scopus.com/inward/record.uri?eid=2-s2. 0-52249096416\&partnerlD=40\&md5=b9ded75a2a6897138471e7bf42bf3c62

61. Mboera LEG, Fanello Cl, Malima RC, Talbert A, Fogliati P, Bobbio F, et al. Comparison of the Paracheck-Pf ${ }^{\otimes}$ test with microscopy, for the confirmation of Plasmodium falciparum malaria in Tanzania. Ann Trop Med Parasitol. 2006;100:115-22. Available from: https://www.scopus.com/inward/record. uri?eid=2-s2.0-33644648486\&partner|D=40\&md5=f509deca8214cdbfcb2950f $3 \mathrm{f} 2 \mathrm{afd} 630$

62. Singh N, Saxena A, Awadhia SB, Shrivastava R, Singh MP. Evaluation of a rapid diagnostic test for assessing the burden of malaria at delivery in India. Am J Trop Med Hyg. 2005;73:855-8.

63. Harutyunyan V. Quality assurance of malaria rapid diagnostic tests (RDT) and its implication for clinical management of malaria. Am J Trop Med Hyg. 2010;83:284.

64. Phiri M, Kobayashi T, Chishimba S, Stresman G, Mharakurwa S, Thuma P, et al. The predictive value of rapid diagnostic tests for gametocytemia identified by RT-PCR. Am J Trop Med Hyg. 2010;83:39. Available from

65. Viana GM, Chamma NN, Barbosa DR, do Carmo EL, Nascimento JM, Peres $J M$, et al. Evaluation of two rapid diagnostic tests for malaria (OptiMAL-IT and PALUTOP $+4^{\circledR}$ ) in an endemic area of Para State, Brazilian Amazon Region. Am J Trop Med Hyg. 2010;83:168.

66. Gerstl S, Dunkley S, Mukhtar A, De Smet M, Baker S, Maikere J. Assessment of two malaria rapid diagnostic tests, with followup of positive pLDH test results, in a hyperendemic falciparum malaria area. Trop Med Int Heal. 2009; 14:92.

67. Abdul W, Rathor HR, Khail AAK, Abdullah MA, Amin U, Ahmad A. Incidence of malaria and comparison of microscopy and rapid diagnostic test in District Dir Lower, Lower Dir, Khyber Pakhtunkhwa, Pakistan. Pakistan J Public Heal. 2016;6(1):51-6.

68. Mahende C, Ngasala B, Lusingu J, Yong T-S, Lushino $P$, Lemnge $M$, et al. Performance of rapid diagnostic test, blood-film microscopy and PCR for the diagnosis of malaria infection among febrile children from Korogwe District, Tanzania. Malar J. 2016;15:391.

69. Zahid U, Badshah N, Nadeem MF, Azam H, Khattak AA. Evaluation of immunochromatographic (ICT) assay and microscopy for malaria diagnosis in endemic district Dera Ismail Khan. Int J Biosci. 2015;6(8):37-42.

70. Bansal R, Jindal N, Sidhu S. Disease dynamics and surveillance of malaria in Malwa region of Punjab and evaluation of RDT test. Br Microbiol Res J. 2013;3(3):339-45.

71. Panchal HK, Desai PB. ICT - a rapid, innovative but simple technique for malaria diagnosis. Int J Pharm Life Sci. 2012;3(4):1581-4.

72. Cook J, Grignard L, Al-Eryani S, Al-Selwei M, Mnzava A, Al-Yarie H, et al. High heterogeneity of malaria transmission and a large sub-patent and diverse reservoir of infection in Wusab As Safil district, Republic of Yemen. Malar J. 2016;15:193.

73. Kamugisha EE, Mazigo HH, Manyama MM, Rambau PP, Mirambo MM, Kataraihya JJ, et al. Low sensitivity but high specificity of ParaHIT-f in diagnosing malaria among children attending outpatient department in Butimba District Hospital, Mwanza, Tanzania. Tanzan J Health Res. 2009; 11(2):97-9.

74. Valecha N, Eapen A, Devi CU, Ravindran J, Aggarwal A, Subbarao SK. Field evaluation of the ICT Malaria P.F./P.V. Immunochromatographic test in India. Ann Trop Med Parasitol. 2002;96(3):333-6.

75. Mendoza NM, Montoya R, Garcia M, Padilla JC, Bruzon LO, Mendoza E, et al. Field evaluation of a rapid diagnostic test for malaria. Biomedica. 2001;21: 313-9.

76. Singer LM, Newman RD, Diarra A, Moran AC, Huber CS, Stennies G, et al. Evaluation of a malaria rapid diagnostic test for assessing the burden of malaria during pregnancy. Am J Trop Med Hyg. 2004;70:481-5.

77. Sumari D, Grimberg BT, Blankenship D, Mugasa J, Mugittu K, Moore L, et al. Application of magnetic cytosmear for the estimation of Plasmodium 
falciparum gametocyte density and detection of asexual stages in asymptomatic children. Malar J. 2016;15:113.

78. Rajendran C, Dube SN. Field evaluation of a rapid immunochromatographic test kit for the diagnosis of Plasmodium falciparum and non-falciparum malaria parasites from Sonitpur district, Assam. J Parasit Dis. 2006;30:94-7.

79. Ahmed SM, Tefera M. Malaria diagnosis and treatment practice following introduction of rapid diagnostic test in selected health posts of Adama Woreda, East Shewa Zone, Oromia Region, Centeral Ethiopia. Value Heal. 2015;18:A868.

80. Kyabayinze DJ, Asiimwe C, Nakanjako D, Nabakooza J, Counihan $\mathrm{H}_{\text {, }}$ Tibenderana JK. Use of RDTs to improve malaria diagnosis and fever case management at primary health care facilities in Uganda. Malar J. 2010;9:200.

81. Zongo S, Farquet V, Ridde V. A qualitative study of health professionals' uptake and perceptions of malaria rapid diagnostic tests in Burkina Faso. Malar J. 2016;15. Available from: https://malariajournal.biomedcentral.com/ articles/10.1186/s12936-016-1241-6.

82. Alumbasi LT, Gagova I, Mikolasova G, Sokolova J, Kulkova N, Silharova B, et al. Decreased occurrence of highland malaria after introduction of point-ofcare rapid diagnostic tests in Kenyan highland near Eldoret in 2250 meters above sea level. Am J Trop Med Hyg. 2013;89:107.

83. Diggle E, Asgary R, Gore-Langton G, Nahashon E, Mungai J, Harrison R, et al. Perceptions of malaria and acceptance of rapid diagnostic tests and related treatment practises among community members and health care providers in Greater Garissa, North Eastern Province, Kenya. Malar J. 2014;13:502.

84. Mubi M, Kakoko D, Ngasala B, Premji Z, Peterson S, Bjorkman A, et al. Malaria diagnosis and treatment practices following introduction of rapid diagnostic tests in Kibaha District, Coast Region, Tanzania. Malar J. 2013;12:293.

85. D'Acremont V, Kahama-Maro J, Swai N, Mtasiwa D, Genton B, Lengeler C. Reduction of anti-malarial consumption after rapid diagnostic tests implementation in Dar Es Salaam: a before-after and cluster randomized controlled study. Malar J. 2011;10:107.

86. Silumbe K, Yukich JO, Hamainza B, Bennett A, Earle D, Kamuliwo M, et al. Costs and cost-effectiveness of a large-scale mass testing and treatment intervention for malaria in Southern Province, Zambia. Malar J. 2015;14 Available from: https://www.scopus.com/inward/record.uri?eid=2-s2.084929627479\&partnerlD=40\&md5=304454031ff2ee1983f014aca5328f5c

87. Hutchinson E, Chandler C, Clarke S, Lal S, Magnussen P, Kayendeke M, et al. "It puts life in us and we feel big": shifts in the local health care system during the introduction of rapid diagnostic tests for malaria into drug shops in Uganda. Crit Public Health. 2015;25:48-62. Available from: https://www. scopus.com/inward/record.uri?eid=2-s2.0-84920525467\&partnerlD=40\&md5 $=745 \mathrm{fe} 989 \mathrm{~d} 46 \mathrm{c} 3 \mathrm{ecbac321e41c6bd61 \textrm {f7 }}$

88. Hasselback L, Crawford J, Chaluco T, Rajagopal S, Prosser W, Watson N. Rapid diagnostic test supply chain and consumption study in Cabo Delgado, Mozambique: estimating stock shortages and identifying drivers of stock-outs. Malar J. 2014;13

89. Moonasar D, Goga AE, Frean J, Kruger P, Chandramohan D. An exploratory study of factors that affect the performance and usage of rapid diagnostic tests for malaria in the Limpopo Province, South Africa. Malar J. 2007;6 Available from: https://www.scopus.com/inward/record.uri?eid=2-s2.034250369507\&partnerlD=40\&md5=9686028ba3917136e149e1d28e02f642

90. Tusiime RN, Wabwire-Mangen F, Najjemba R. Knowledge and compliance of health workers to malaria rapid diagnostic test guidelines in Rukungiri District, western Uganda, 2010. Am J Trop Med Hyg. 2010;83:283-4.

91. Mbonye A, Magnussen P, Lal S, Hansen K, Cundill B, Chandler C, et al. A cluster randomised trial introducing rapid diagnostic tests into the private health sector in Uganda: Impact on appropriate treatment of malaria. Trop Med Int Heal. 2013;18:74

92. Chandler CIR, Hall-Clifford R, Asaph T, Pascal M, Clarke S, Mbonye AK. Introducing malaria rapid diagnostic tests at registered drug shops in Uganda: limitations of diagnostic testing in the reality of diagnosis. Soc Sci Med. 2011;72:937-44.

93. Mbonye AK, Ndyomugyenyi R, Turinde A, Magnussen P, Clarke S, Chandler C. The feasibility of introducing rapid diagnostic tests for malaria in drug shops in Uganda. Malar J. 2010;9:367.

94. Brieger WR, Orji BC, Otolorin E, Ndekhedehe E, Nwadike JU. Establishing integrated community management of malaria, pneumonia and diarrhea in selected two Local Government Areas, Akwa Ibom State Nigeria. Am J Trop Med Hyg. 2011:85:173.

95. Uzochukwu BSC, Chiegboka LO, Enwereuzo C, Nwosu U, Okorafor D, Onwujekwe $\mathrm{OE}$, et al. Examining appropriate diagnosis and treatment of malaria: availability and use of rapid diagnostic tests and artemisinin-based combination therapy in public and private health facilities in south East Nigeria. BMC Public Health. 2010;10 Available from: https://www.scopus. com/inward/record.uri?eid=2-s2.0-77955533157\&partnerlD=40\&md5=e1ae 4e9700a52a147743faf591cc2bfb

96. Boadu NY, Amuasi J, Ansong D, Einsiedel E, Menon D, Yanow SK. Challenges with implementing malaria rapid diagnostic tests at primary care facilities in a Ghanaian district: a qualitative study. Malar J. 2016;15:126.

97. Hansen KS, Pedrazzoli D, Mbonye A, Clarke S, Cundill B, Magnussen P, et al. Willingness-to-pay for a rapid malaria diagnostic test and artemisinin-based combination therapy from private drug shops in Mukono District, Uganda. Health Policy Plan. 2013;28:185-96. Available from: https://www.ncbi.nlm. nih.gov/pmc/articles/PMC3584993/.

98. Silumbe K, Chiyende E, Finn TP, Desmond M, Puta C, Hamainza B, et al. A qualitative study of perceptions of a mass test and treat campaign in southern Zambia and potential barriers to effectiveness. Malar J. 2015;14:171.

99. Ranasinghe S, Ansumana R, Lamin JM, Bockarie AS, Bangura U, Buanie JAG, et al. Attitudes toward home-based malaria testing in rural and urban Sierra Leone. Malar J. 2015;14:80.

100. Ezeoke OP, Ezumah NN, Chandler CC, Mangham-Jefferies LJ, Onwujekwe $\mathrm{OE}$, Wiseman $\mathrm{V}$, et al. Exploring health providers' and community perceptions and experiences with malaria tests in south-East Nigeria: a critical step towards appropriate treatment. Malar J. 2012;11:368.

101. Boadu NYA, Ansong D, Amuasi JH, Nguah SB, Arhin B, Somuah S, et al. A review of malaria rapid diagnostic tests (RDT) guideline implementation in a district hospital in Ghana: has rapid testing been prioritized? Am J Trop Med Hyg. 2012;87:397.

102. Masaninga F, Sekeseke-Chinyama M, Malambo T, Moonga H, Babaniyi $O$ Counihan $\mathrm{H}$, et al. Finding parasites and finding challenges: improved diagnostic access and trends in reported malaria and anti-malarial drug use in Livingstone district, Zambia. Malar J. 2012;11:341.

103. Ospina OL, Cortés LJ, Cucunubá ZM, Mendoza NM, Chaparro P. Characterization of the National Malaria Diagnostic Network, Colombia, 2006-2010. Biomedica. 2012;32:46-59.

104. Fenny AP, Hansen KS, Enemark U, Asante FA. Quality of uncomplicated malaria case management in Ghana among insured and uninsured patients. Int J Equity Health. 2014;13:63.

105. Lima J, Abeyasinghe RR, Fitzpatrick R, Fernando SD. Diagnosis and treatment of malaria by health care providers: findings from a post conflict district in Sri Lanka. Int Heal. 2012;4(2):148-50.

106. Aborigo RA, Atuguba F, Chatio S, Adoctor J, Binka FN, Allen DR. Malaria diagnosis and treatment behaviors among public and private sector health care providers in a phase IV trial in Northern Ghana. Am J Trop Med Hyg. 2011;85:270.

107. Hansen K, Mbonye A, Lal S, Magnussen P, Clarke S. Incremental costeffectiveness analysis of introducing rapid diagnostic testing for malaria into registered drug shops in Uganda. Trop Med Int Heal. 2013;18:156.

108. Faye A, Ndiaye P, Diagne-Camara M, Badiane O, Wone I, Diongue M, et al. Economic evaluation of rapid diagnostic tests in malaria treatment. Sante Publique. 2010;22:617-23. Available from: https://www.scopus.com/inward/ record.uri?eid=2-s2.0-79951541047\&partner|D=40\&md5=fe9b9507452f91192 25805afef55e22d

109. Ansah EK, Whitty CJ, Yeung S, Hansen K. Cost-effectiveness analysis of introducing rapid diagnostic tests (RDTs) for malaria diagnosis in public health centers where microscopy is available and peripheral clinics where only clinical diagnosis is available: The case of Ghana. Am J Trop Med Hyg. 2011;85:350.

110. Yukich J, D’Acremont V, Kahama J, Swai N, Lengeler C. Cost savings with rapid diagnostic tests for malaria in low-transmission areas: evidence from Dar es Salaam, Tanzania. Am J Trop Med Hyg. 2010;83:61-8. Available from: https://www.scopus.com/inward/record.uri?eid=2-s2.0-77954572778\&partner ID $=40 \&$ md5=6286ccc4342cccf671005a712762d94b

111. Uzochukwu BSC, Obikeze EN, Onwujekwe OE, Onoka CA, Griffiths UK. Costeffectiveness analysis of rapid diagnostic test, microscopy and syndromic approach in the diagnosis of malaria in Nigeria: implications for scaling-up deployment of ACT. Malar J. 2009;8 Available from: https://www.scopus. com/inward/record.uri?eid=2-s2.0-72849149273\&partnerlD=40\&md5=557b4 $152196 c d 7 d 413$ b97d4f42053605

112. Uzochukwu BS, Onwujekwe OE, Uguru NP, Ughasoro MD, Ezeoke OP. Willingness to pay for rapid diagnostic tests for the diagnosis and treatment of malaria in Southeast Nigeria: ex post and ex ante. Int J Equity Health. 2010;9 Available from: https://www.scopus.com/inward/record.uri?eid=2-s2. 0-77649131952\&partnerlD=40\&md5=f394ae1d1 c968dc252b5734a19ed2243 
113. Mbonye AK, Magnussen P, Chandler CIR, Hansen KS, Lal S, Cundill B, et al. Introducing rapid diagnostic tests for malaria into drug shops in Uganda: design and implementation of a cluster randomized trial. Trials. 2014;15 Available from: https://www.scopus.com/inward/record.uri?eid=2-s2.084904784771\&partnerlD=40\&md5=97bb6058b8b76a260e071eab67535fb6

114. Mbonye AK, Clarke SE, Lal S, Chandler Cl, Hutchinson E, Hansen KS, et al. Introducing rapid diagnostic tests for malaria into registered drug shops in Uganda: lessons learned and policy implications. Malar J. 2015;14:448.

115. Ishengoma D, Lwitiho S, Madebe R, Persson O, Nyagonde N, Vestergaard L, et al. Using rapid diagnostic tests (RDTS) as source of malaria parasite DNA for molecular analyses. Am J Trop Med Hyg. 2010;83:284.

116. Giang DC, Duong TN, Ha DTM, Nhan HT, Wolbers M, Nhu NTQ, et al. Prospective evaluation of GeneXpert for the diagnosis of HIV- negative pediatric TB cases. BMC Infect Dis. 2015;15:70.

117. Al-Ateah SM, Al-Dowaidi MM, El-Khizzi NA. Evaluation of direct detection of Mycobacterium tuberculosis complex in respiratory and non-respiratory clinical specimens using the Cepheid gene Xpert ${ }^{\oplus}$ system. Saudi Med J. 2012;33:1100-5.

118. Calligaro GL, Theron G, Khalfey H, Peter J, Meldau R, Matinyenya B, et al. Burden of tuberculosis in intensive care units in Cape Town, South Africa, and assessment of the accuracy and eff ect on patient outcomes of the Xpert MTB/RIF test on tracheal aspirate samples for diagnosis of pulmonary tuberculosis: a prospective burden. Lancet Respir Med. 2015;3:621-30.

119. Raizada N, Sachdeva KS, Sreenivas A, Kulsange S, Gupta RS, Thakur R, et al. Catching the missing million: experiences in enhancing TB \& DR-TB detection by providing upfront Xpert MTB/RIF testing for people living with HIV in India. PLoS One. 2015;10:e0116721.

120. Raizada N, Sachdeva KS, Nair SA, Kulsange S, Gupta RS, Thakur R, et al. Enhancing TB case detection: experience in offering upfront Xpert MTB/RIF testing to pediatric presumptive TB and DR TB cases for early rapid diagnosis of drug sensitive and drug resistant TB. PLoS One. 2014;9:e105346.

121. Zar HJ, Workman L, Isaacs W, Dheda K, Zemanay W, Nicol MP. Rapid diagnosis of pulmonary tuberculosis in African children in a primary care setting by use of Xpert MTB/RIF on respiratory specimens: a prospective study. Lancet Glob Heal. 2013;1:e97-104.

122. Lawn SD, Brooks SV, Kranzer K, Nicol MP, Whitelaw A, Vogt M, et al. Screening for HIV-associated tuberculosis and rifampicin resistance before antiretroviral therapy using the Xpert MTB/RIF assay: a prospective study. PLoS Med. 2011;8:e1001067.

123. Nicol MP, Workman L, Isaacs W, Munro J, Black F, Eley B, et al. Accuracy of the Xpert MTB/RIF test for the diagnosis of pulmonary tuberculosis in children admitted to hospital in Cape Town, South Africa: a descriptive study. Lancet Infect Dis. 2011;11:819-24.

124. Bholla M, Kapalata N, Masika E, Chande H, Jugheli L, Sasamalo M, et al. Evaluation of $X$ pert ${ }^{\oplus}$ MTB/RIF and Ustar EasyNAT ${ }^{T M}$ TB IAD for diagnosis of tuberculous lymphadenitis of children in Tanzania: a prospective descriptive study. BMC Infect Dis. 2016;16 Available from: https://www.scopus.com/ inward/record.uri?eid=2-s2.0-84973279127\&partnerlD=40\&md5=4932326a75 c8a860e53501bf4b49cf64

125. Held M, Laubscher M, Mears S, Dix-Peek S, Workman L, Zar H, et al. Diagnostic accuracy of the Xpert MTB/RIF assay for extrapulmonary tuberculosis in children with musculoskeletal infections. Pediatr Infect Dis J. 2016;35(11):1165-8.

126. Okumu A. Comparison of performance between Ziehl Neelsen (ZN) microscopy and the Xpert MTB/RIF assay in detection of $M$. tuberculosis in sputum at KEMRI/CDC TB lab. Trop Med Int Heal. 2012;17:23-4.

127. Dhasmana DJ, Ross C, Bradley CJ, Connell DW, George PM, Singanayagam A, et al. Performance of Xpert MTB/RIF in the diagnosis of tuberculous mediastinal lymphadenopathy by endobronchial ultrasound. Ann Am Thorac Soc. 2014;11:392-6. Available from: https://www.scopus.com/inward/ record. uri?eid=2-s2.0-84898755132\&partnerlD=40\&md5=a3ac965c9cfe0b4e0 $3166046 \mathrm{a} 679 \mathrm{c} 6 \mathrm{fe}$

128. Kerkhoff AD, Wood R, Vogt M, Lawn SD. Predictive value of anemia for tuberculosis in HIV-infected patients in sub-saharan africa: an indication for routine microbiological investigation using new rapid assays. J Acquir Immune Defic Syndr. 2014;66:33-40. Available from: https://www.scopus. com/inward/record.uri?eid=2-s2.0-84898541893\&partnerlD=40\&md5=88531c ae379708da4039fc0bcea8abcc

129. Gous N, Scott LE, Khan S, Reubenson G, Coovadia A, Stevens W. Diagnosing childhood pulmonary tuberculosis using a single sputum specimen on Xpert MTB/RIF at point of care. South African Med J. 2015;105(12):1044-8.
130. Nhu NTQ, Heemskerk D, Thu DDA, Chau TTH, Mai NTH, Nghia HDT, et al. Evaluation of GeneXpert MTB/RIF for diagnosis of tuberculous meningitis. J Clin Microbiol. 2014;52:226-33. Available from: http://www.ncbi.nlm.nih.gov/ pubmed/24197880

131. Zar HJ, Workman L, Boehme C, Eley B, Nicol MP. Cartridge-based automated nucleic acid amplification test (XPERT MTB/RIF) for the diagnosis of pulmonary tuberculosis in HIV-infected and uninfected children: a prospective study. Am J Respir Crit Care Med. 2011;183

132. Peñata A, Salazar R, Castaño T, Bustamante J, Ospina S. Molecular diagnosis of extrapulmonary tuberculosis and sensitivity to rifampicin with an automated real-time method. Biomedica. 2016:36:78-89. Available from: https://www.ncbi.n/m.nih.gov/pubmed/27622628

133. Wang Y, Williams C, Merritt S, Kasinathan V, Young AN. Evaluation of GenXpert MTB/RIF assay on AFB-smear positive respiratory samples. J Mol Diagnostics. 2010;12:885-6.

134. Boehme CC, Nicol MP, Nabeta P, Michael JS, Gotuzzo E, Tahirli R, et al. Feasibility, diagnostic accuracy, and effectiveness of decentralised use of the Xpert MTB/RIF test for diagnosis of tuberculosis and multidrug resistance: a multicentre implementation study. Lancet. 2011;377:1495-505. Available from: https://www.scopus.com/inward/record.uri?eid=2-s2.079955571240\&partnerlD=40\&md5=277e1119f3fb6713ffc233e7d291fec7

135. Pandie S, Peter JG, Kerbelker ZS, Meldau R, Theron G, Govender U, et al. Diagnostic accuracy of quantitative PCR (Xpert MTB/RIF) for tuberculous pericarditis compared to adenosine deaminase and unstimulated interferon$Y$ in a high burden setting: a prospective study. BMC Med. 2014;12:101.

136. Naidoo P, Dunbar R, Lombard C, du Toit E, Caldwell J, Detjen A, et al. Comparing tuberculosis diagnostic yield in smear/culture and Xpert(R) MTB/ RIF-based algorithms using a non-randomised stepped-wedge design. PLoS One. 2016;11:e0150487.

137. O'Donnell MR, Pym A, Jain P, Munsamy V, Wolf A, Karim F, et al. A novel reporter phage to detect tuberculosis and rifampin resistance in a high-HIVburden population. J Clin Microbiol. 2015;53:2188-94. Available from: https://www.ncbi.nlm.nih.gov/pubmed/25926493

138. Lawn SD, Kerkhoff AD, Vogt M, Wood R. Diagnostic accuracy of a low-cost, urine antigen, point-of-care screening assay for HIV-associated pulmonary tuberculosis before antiretroviral therapy: a descriptive study. Lancet Infect Dis. 2012;12:201-9. Available from: https://www.scopus.com/inward/record.uri?eid= 2-s2.0-84857191744\&partnerID=40\&md5=a967fc38a6a1ce00871f4074907dd524

139. Cox HS, Daniels JF, Muller O, Nicol MP, Cox V, van Cutsem G, et al. Impact of decentralized care and the Xpert MTB/RIF test on rifampicin-resistant tuberculosis treatment initiation in Khayelitsha, South Africa. Open Forum Infect Dis. 2015;2. Available from: https://academic.oup.com/ofid/article/2/1/ ofv014/1462784

140. Maghimbi A, Majigo M, Mashinji V, Loy G, Mwakyusa S. Challenges fueling the complexities of TB Diagnosis \& TBHIV comorbidity in Tanzania- IHV experience. J Acquir Immune Defic Syndr. 2014;65:70.

141. Lawn SD, Kerkhoff A, Burton R, Schutz C, Van Wyk G, Vogt M, et al. Massive diagnostic yield of HIV-associated tuberculosis using rapid urine assays in South Africa. Top Antivir Med. 2014;22, 422. Available from: http://www. croiconference.org/sessions/massive-diagnostic-yield-hiv-associatedtuberculosis-using-rapid-urine-assays-south-africa.

142. Ssengooba W, Respeito D, Mambuque E, Blanco S, Bulo H, Mandomando I, et al. Do xpert MTB/RIF cycle threshold values provide information about patient delays for tuberculosis diagnosis? PLoS One. 2016;11. Available from: http://journals.plos.org/plosone/article?id=10.1371/journal.pone.0162833.

143. Hoang TT, Nguyen NV, Dinh SN, Nguyen HB, Cobelens F, Thwaites G, et al. Challenges in detection and treatment of multidrug resistant tuberculosis patients in Vietnam. BMC Public Health. 2015;15:980.

144. Trajman A, Durovni B, Saraceni V, Menezes A, Cordeiro-Santos M, Cobelens F, et al. Impact on patients' treatment outcomes of XpertMTB/RIF implementation for the diagnosis of tuberculosis: follow-up of a steppedwedge randomized clinical trial. PLoS One. 2015;10 Available from: https:// www.scopus.com/inward/record.uri?eid=2-s2.0-84928678299\&partnerlD= 40\&md5=3f265d1ec805297c33ecaaab7f7f4e41

145. Churchyard GJ, Stevens WS, Mametja LD, McCarthy KM, Chihota V, Nicol MP, et al. Xpert MTB/RIF versus sputum microscopy as the initial diagnostic test for tuberculosis: a cluster-randomised trial embedded in south African rollout of Xpert MTB/RIF. Lancet Glob Heal. 2015;3:e450-7.

146. Lawn SD, Kerkhoff AD, Vogt M, Wood R. Clinical significance of lipoarabinomannan detection in urine using a low-cost point-of-care diagnostic assay for HIV-associated tuberculosis. AIDS. 2012;26:1635-43. 
Available from: https://www.scopus.com/inward/record.uri?eid=2-s2.084865494970\&partnerlD=40\&md5=ef0113dc70dda17afca8dd611 e265060

147. Durovni B, Saraceni V, van den Hof S, Trajman A, Cordeiro-Santos M, Cavalcante S, et al. Impact of Replacing Smear Microscopy with Xpert MTB/ RIF for Diagnosing Tuberculosis in Brazil: A Stepped-Wedge ClusterRandomized Trial. PLoS Med. 2014;11. Available from: http://journals.plos. org/plosmedicine/article?id=10.1371/journal.pmed. 1001766

148. Adelman M, Kurbatova E, Wang W, Leonard M, White N, McFarland D, et al. Cost analysis of a nucleic acid amplification test for pulmonary tuberculosis. Clin Transl Sci. 2014;7:236.

149. Naidoo P, Dunbar R, Du Toit E, Van Niekerk M, Squire SB, Beyers N, et al. Comparing laboratory costs of smear/culture and Xpert ${ }^{\oplus}$ MTB/RIF-based tuberculosis diagnostic algorithms. Int J Tuberc Lung Dis. 2016;20:1377-85.

150. Du Toit E, Squire SB, Dunbar R, Machekano R, Madan J, Beyers N, et al. Comparing multidrug-resistant tuberculosis patient costs under molecular diagnostic algorithms in South Africa. Int J Tuberc Lung Dis. 2015;19:960-8. Available from: https://www.scopus.com/inward/record. uri?eid=2-s2.0-84938249021 \&partnerlD $=40 \&$ md5 $=9568 c 8590003 \mathrm{a} 4 \mathrm{e} 254380$ 9e10e91971d

151. de Camargo KR Jr, Guedes CR, Caetano R, Menezes A, Trajman A. The adoption of a new diagnostic technology for tuberculosis in two Brazilian cities from the perspective of patients and healthcare workers: a qualitative study. BMC Health Serv Res. 2015;15:275.

152. Telles MA da S, Menezes A, Trajman A. Bottlenecks and recommendations for the incorporation of new technologies in the tuberculosis laboratory network in Brazil. J Bras Pneumol. 2012;38:766-70.

153. Durovni B, Saraceni V, Cordeiro-Santos M, Cavalcante S, Soares E, Lourenço C, et al. Operational lessons drawn from pilot implementation of Xpert MTB/Rif in Brazil. Bull World Health Organ. 2014;92:613-7. Available from: https://www.scopus.com/inward/record.uri?eid=2-s2.0-84905236134\&partner ID $=40 \&$ md5=69cd50a85b5fc2063ba670217d3f2b96

154. Perkins MD, Conde MB, Martins M, Kritski AL. Serologic diagnosis of tuberculosis using a simple commercial multiantigen assay. Chest. 2003;123:107-12.

155. Gounder C, De Queiroz Mello FC, Conde MB, Bishai WR, Kritski AL, Chaisson $R E$, et al. Field evaluation of a rapid immunochromatographic test for tuberculosis. J Clin Microbiol. 2002:40:1989-93.

156. Dumaplin D, Ferrer M, Divinagracia EM, Cabana R, Sirilan L, GuzmanTrivilegio $R$, et al. Clinical evaluation of a lateral flow serologic test in the rapid diagnosis of pulmonary $\mathrm{TB}$ in a public-private mix for dots setting in Iloilo City, Philippines. Respirology. 2010;15:63.

157. Dumaplin D, Ferrer M, Divinagracia EM, Sirilan L, Cabana R, GuzmanTrivilegio $\mathrm{R}$, et al. Clinical utility of a lateral flow serologic test in the rapid diagnosis of pulmonary TB in a public-private mix for DOTS setting in Iloilo City, Philippines. Eur Respir J. 2011;38(S55):4384.

158. Garcia-Cruz AE, Olvera-Castillo R, Hernandez-Zarza NM, Antuna-Puente $B$ Uribe-Campero L, Rivas-Ruiz R, et al. Diagnosis of pulmonary tuberculosis by rapid immunochromatography. Rev Med Inst Mex Seguro Soc. 2011:49:3739.

159. Al-Jebouri MM, Wahid NM. An evaluation of QuantiFERON-TB gold in-tube and immunological tests for TB diagnosis in Iraqi patients. Br J Med Med Res. 2014;4(13):2546-54.

160. Asceric M, Nadarevic A, Avdic S, Vrabac-Mujcinagic M, Nukic S, Mujcinovic Z. Hexagon TB for the rapid diagnosis of lung TBC in praxis. Bosn J basic Med Sci. 2007;7:218-21

161. Van Beek SC, Nhung NV, Sy DN, Sterk PJ, Tiemersma EW, Cobelens FGJ. Measurement of exhaled nitric oxide as a potential screening tool for pulmonary tuberculosis. Int J Tuberc Lung Dis. 2011;15:185-91.

162. Barreto LBPF, Lourenço MCS, Rolla VC, Veloso VG, Huf G. Use of amplified mycobacterium tuberculosis direct test in respiratory samples from HIVinfected patients in Brazil. J Bras Pneumol. 2014;40:148-54.

163. Moura AS, Lopes HM, Mourão MV, Morais MH. Performance of a rapid diagnostic test for the detection of visceral leishmaniasis in a large urban setting. Rev Soc Bras Med Trop. 2013;46:589-93. Available from: https:// www.ncbi.nlm.nih.gov/pubmed/24270249

164. Celeste BJ, Sanchez MCA, Almeida RPD, Castelo Branco CMF, Lindoso JAL, Paniago AMM, et al. Evaluation of immunochromatographic assay with recombinant antigen $\mathrm{K} 39$, using whole blood, serum and oral fluid, in the diagnosis of visceral leishmaniasis in Brazilian endemic areas. Trop Med Int Heal. 2015;20:210.

165. Alcoba G, Atia AA, Mumina A, Sterk E, Antierens A, Chappuis F. Impact of pediatric and adult acute malnutrition on visceral leishmaniasis RK39 diagnostic test results and clinical outcome in the Sudan. Am J Trop Med Hyg. 2014;91:335.

166. Moreno EC, Melo MN, Lambertucci JR, Serufo JC, Andrade ASR, Antunes $C M F$, et al. Diagnosing human asymptomatic visceral leishmaniasis in an urban area of the state of Minas Gerais, using serological and molecular biology techniques. Rev Soc Bras Med Trop. 2006;39:421-7.

167. Goswami RP, Das S, Ray Y, Rahman M, Ray Y. Testing urine samples with rK39 strip as the simplest non-invasive field diagnosis for visceral leishmaniasis: an early report from eastern India. J Postgr Med. 2012;58:1804. Available from: https://www.scopus.com/inward/record.uri?eid=2-s2.084867300628\&partnerlD=40\&md5=ed260b49b2170294adaff92ea4457e80

168. Gavgani AM, Khademvatan S, Ghazanchaei A. KAtex antigen-detection test as a diagnostic tool for latent visceral leishmaniasis cases. Afr J Biotechnol. 2008;7:852-9. Available from: https://www.scopus.com/ inward/record.uri?eid=2-s2.0-42149133849\&partnerlD=40\&md5=09c6536f4 $7 f 2227 f 7 c 86240 \mathrm{bc} 5572380$

169. Assis TS, Guimarães PN, Oliveira E, Peruhype-Magalhães V, Gomes LI, Rabello A. Study of implementation and direct cost estimates for diagnostic tests for human visceral leishmaniasis in an urban area in Brazil. Cad Saude Publica. 2015;31:212736. Available from: https://www.ncbi.nlm.nih.gov/pubmed/26735380

170. Assis TM, Guimarães PN, Oliveira E, Peruhype-Magalhães V, Gomes LI, Rabello A. Acceptance and potential barriers to effective use of diagnostic tests for visceral leishmaniasis in an urban area in Brazil. Rev Soc Bras Med Trop. 2016; 49:241-4. Available from: https://www.ncbi.nlm.nih.gov/pubmed/27192596

171. Akhoundi B, Mohebali M, Shojaee S, Jalali M, Kazemi B, Bandehpour M, et al. Rapid detection of human and canine visceral leishmaniasis: assessment of a latex agglutination test based on the A2 antigen from amastigote forms of Leishmania infantum. Exp Parasitol. 2012/12/28. 2013;133:307-13.

172. McBride AJA, Santos BL, Queiroz A, Santos AC, Hartskeerl RA, Reis MG, et al. Evaluation of four whole-cell Leptospira-based serological tests for diagnosis of urban leptospirosis. Clin Vaccine Immunol. 2007/07/25. 2007;14:1245-8. Available from: https://www.ncbi.nlm.nih.gov/pubmed/ 17652521

173. Eapen CK, Sugathan S, Kuriakose M, Abdoel T, Smits HL. Evaluation of the clinical utility of a rapid blood test for human leptospirosis. Diagn Microbiol Infect Dis. 2002:42:221-5. Available from: https://www.scopus.com/inward/ record.uri?eid=2-s2.0-0036238582\&partnerlD=40\&md5=1165daf99fbda949d 1 993dd20672ed14

174. Cermeño Vivas J, Sandoval de Mora M, Bognammo J, Caraballo A. Aspectos epidemiológicos y clínicos de la leptospirosis en el estado Bolívar, Venezuela 1999-2000: comparación de LEPTO-Dipstick y antígeno termorresistente de Leptospira (TR). Investig Clin. 2005;46:317-28.

175. Obregon AM, Fernandez C, Rodriguez I, Rodriguez J, Zamora Y. Laboratory advances in serologic diagnosis and research of human leptospirosis in Cuba. Rev Cubana Med Trop. 2007:59:63-7.

176. Nabity SA, Ribeiro GS, Takahashi D, Medeiros MA, Lessa C, Damião A, et al. Evaluation of a dual path platform (DPP) assay for the rapid diagnosis of leptospirosis. Am J Trop Med Hyg. 2011;85:167.

177. Yahathugoda TC, Supali T, Rao RU, Djuardi Y, Stefani D, Pical F, et al. A comparison of two tests for filarial antigenemia in areas in Sri Lanka and Indonesia with low-level persistence of lymphatic filariasis following mass drug administration. Parasit Vectors. 2015;8:369. Available from: https://www. ncbi.nlm.nih.gov/pubmed/26168919

178. Jamail M, Andrew K, Junaidi D, Krishnan AK, Faizal M, Rahmah N. Field validation of sensitivity and specificity of rapid test for detection of Brugia malayi infection. Trop Med Int Heal. 2005;10:99-104. Available from: https:// www.ncbi.nlm.nih.gov/pubmed/15655019

179. Dewi RM, Tuti S, Ganefa S, Anwar C, Larasati R, Ariyanti E, et al. Brugia rapid $^{T M}$ antibody responses in communities of Indonesia in relation to the results of "transmission assessment surveys" (TAS) for the lymphatic filariasis elimination program. Parasit Vectors. 2015;8:499. Available from: https:// www.ncbi.nlm.nih.gov/pubmed/26427536

180. Oliveira CM de. Validação dos anticorpos monoclonais Og4c3 e ad12 no diagnóstico da filariose bancroftiana em inquérito populacional. [Recife]: s.n; 2003. Available from: http://www.cpqam.fiocruz.br/bibpdf/ 2003oliveira-cm.pdf.

181. Oliveira PA dos S. Avaliação da acurácia de diferentes testes laboratoriais no diagnóstico da filariose em crianças e adolescentes. [Recife]: s.n; 2010. Available from: http://www.cpqam.fiocruz.br/bibpdf/2010oliveira-pas.pdf

182. Dong B, Galindo CM, Shin E, Acosta CJ, Page AL, Wang M, et al. Optimizing typhoid fever case definitions by combining serological tests in a large 
population study in Hechi City, China. Epidemiol Infect. 2007;135:1014-20. Available from: https://www.ncbinlm.nih.gov/pubmed/17217551

183. Dutta S, Sur D, Manna B, Sen B, Deb AK, Deen JL, et al. Evaluation of newgeneration serologic tests for the diagnosis of typhoid fever: data from a community-based surveillance in Calcutta, India. Diagn Microbiol Infect Dis. 2006:56:359-65. Available from: https://www.scopus.com/inward/record. uri?eid=2-s2.0-33845316135\&partnerlD=40\&md5=ced40ela294355f02959449 $504884 \mathrm{cf3}$

184. Tanyigna KB, Ogor JO. The sensitivity of diazo test in the diagnosis of enteric fevers. African J Clin Exp Microbiol. 2008;9(3):115-6.

185. Adriko M, Standley CJ, Tinkitina B, Tukahebwa EM, Fenwick A, Fleming FM, et al. Evaluation of circulating cathodic antigen (CCA) urine-cassette assay as a survey tool for Schistosoma mansoni in different transmission settings within Bugiri District, Uganda. Acta Trop. 2014;136:50-7. Available from: https://www.ncbi.nlm.nih.gov/pubmed/24727052

186. Silveira AMS, Costa EGD, Ray D, Suzuki BM, Hsieh MH, Fraga LA de O, et al. Evaluation of the CCA Immuno-chromatographic test to diagnose Schistosoma mansoni in Minas Gerais State, Brazil. PLoS Negl Trop Dis. 2016;10: e0004357. Available from: https:/www.ncbi.nlm.nih.gov/pubmed/26752073

187. Sheele JM, Kihara JH, Baddorf S, Byrne J, Ravi B. Evaluation of a novel rapid diagnostic test for Schistosoma haematobium based on the detection of human immunoglobulins bound to filtered Schistosoma haematobium eggs. Tropical Med Int Health. 2013;18:477-84.

188. Shih HI, Hsu HC, Wu CJ, Lin CH, Chang CM, Tu YF, et al. Applications of a rapid and sensitive dengue DUO rapid immunochromatographic test kit as a diagnostic strategy during a dengue type 2 epidemic in an Urban City. PLoS One. 2016;11 Available from: https://www.scopus.com/inward/record.uri?eid=2-s2. 0-84978629035\&partnerl|D=40\&md5=0b1d01962ffd5dd73cc2c46ee633b209

189. Alzahrani A. Knowledge and practice of primary health-care physicians regarding the dengue fever in Makkah Al-Mokarramah city, 2013. Int I Med Sci Public Heal. 2015;4(2):266-74. Available from: http://www.scopemed.org/ fulltextpdf.php?mno=175080

190. Grossi MA de F, Leboeuf MAA, Andrade ARCD, Lyon S, Antunes CM de F, Buhrer-Sekula S. The influence of ML Flow test in leprosy classification. Rev Soc Bras Med Trop. 2008;41(s2):34-8.

191. Duthie MS, Orcullo FM, Maghanoy A, Balagon MF. Need for, and acceptability of, rapid diagnostic tests that can facilitate the diagnosis of leprosy. Lepr Rev. 2016;87:158-70.

192. Shah V, Ferrufino L, Gilman RH, Ramirez M, Saenza E, Malaga E, et al. Field evaluation of the InBios Chagas detect plus rapid test in serum and wholeblood specimens in Bolivia. Clin Vaccine Immunol. 2014;21:1645-9.

193. Mpanya A, Mbo F, Lumbala C, Hasker E, llunga J, Lutumba P, et al. Direct comparison of the card agglutination test for trypanosomiasis (CATT) and a rapid diagnostic test in a highly endemic district. Trop Med Int Heal. 2015; 20:325-6.

194. Mukherjee P, Ghosh S, Ramamurthy T, Bhattacharya MK, Nandy RK, Takeda Y, et al. Evaluation of a rapid immunochromatographic dipstick kit for diagnosis of cholera emphasizes its outbreak utility. Jpn J Infect Dis. 2010;63:234-8.

195. Banoo S, Bell D, Bossuyt P, Herring A, Mabey D, Poole F, et al. Evaluation of diagnostic tests for infectious diseases: general principles. Nat Rev Microbiol. 2006:4:521-31.

196. Abba K, Deeks JJ, Olliaro P, Naing CM, Jackson SM, Takwoingi Y, et al. Rapid diagnostic tests for diagnosing uncomplicated $\mathrm{P}$. falciparum malaria in endemic countries. Cochrane Database Syst Rev. 2011:CD008122. Available from: https://www.ncbi.nlm.nih.gov/pubmed/21735422.

197. Abba K, Kirkham AJ, Olliaro PL, Deeks JJ, Donegan S, Garner P, et al. Rapid diagnostic tests for diagnosing uncomplicated non-falciparum or Plasmodium vivax malaria in endemic countries. Cochrane Database Syst Rev. 2014: CD011431. Available from: https://www.ncbi.nlm.nih.gov/pubmed/25519857

198. Kattenberg JH, Ochodo EA, Boer KR, Schallig HD, Mens PF, Leeflang MM. Systematic review and meta-analysis: rapid diagnostic tests versus placental histology, microscopy and PCR for malaria in pregnant women. Malar J, Available from. 2011;10:321. https:/www.ncbi.nlm.nih.gov/pubmed/22035448

199. Steingart KR, Schiller I, Horne DJ, Pai M, Boehme CC, Dendukuri N. Xpert ${ }^{\circledR}$ MTB/RIF assay for pulmonary tuberculosis and rifampicin resistance in adults. Cochrane Database Syst Rev. 2014:CD009593. Available from: https:// www.ncbi.nlm.nih.gov/pubmed/24448973

200. Chang K, Lu W, Wang J, Zhang K, Jia S, Li F, et al. Rapid and effective diagnosis of tuberculosis and rifampicin resistance with Xpert MTB/RIF assay: a meta-analysis. J Infect. 2012;64:580-8. Available from: https://www. ncbi.nlm.nih.gov/pubmed/22381459
201. Shah M, Hanrahan C, Wang ZY, Dendukuri N, Lawn SD, Denkinger CM, et al. Lateral flow urine lipoarabinomannan assay for detecting active tuberculosis in HIV-positive adults. Cochrane Database Syst Rev. 2016:CD011420. Available from: https://www.ncbi.n/m.nih.gov/pubmed/27163343

202. Maia Z, Lírio M, Mistro S, Mendes CM, Mehta SR, Badaro R. Comparative study of rK39 Leishmania antigen for serodiagnosis of visceral leishmaniasis: systematic review with meta-analysis. PLoS Negl Trop Dis. 2012;6:e1484. Available from: https://www.ncbi.nlm.nih.gov/pubmed/22303488

203. Boelaert M, Verdonck K, Menten J, Sunyoto T, van Griensven J, Chappuis F, et al. Rapid tests for the diagnosis of visceral leishmaniasis in patients with suspected disease. Cochrane Database Syst Rev. 2014:CD009135. Available from: https://www.ncbi.nlm.nih.gov/pubmed/24947503

204. Blacksell SD, Doust JA, Newton PN, Peacock SJ, Day NP, Dondorp AM. A systematic review and meta-analysis of the diagnostic accuracy of rapid immunochromatographic assays for the detection of dengue virus lgM antibodies during acute infection. Trans R Soc Trop Med Hyg. 2006;100:77584. Available from: https://www.ncbi.nlm.nih.gov/pubmed/16551470

205. Zhang H, Li W, Wang J, Peng H, Che X, Chen X, et al. NS1-based tests with diagnostic utility for confirming dengue infection: a meta-analysis. Int J Infect Dis. 2014;26:57-66. Available from: https:/www.ncbi.nlm.nih.gov/pubmed/24984164

206. Ochodo EA, Gopalakrishna G, Spek B, Reitsma JB, van Lieshout L, Polman K, et al. Circulating antigen tests and urine reagent strips for diagnosis of active schistosomiasis in endemic areas. Cochrane Database Syst Rev. 2015: CD009579. Available from: https://www.ncbi.nlm.nih.gov/pubmed/25758180

207. Moura RS, Calado KL, Oliveira ML, Bührer-Sékula S. Leprosy serology using PGL-I: a systematic review. Rev Soc Bras Med Trop. 2008;41(Suppl 2):11-8. Available from: https://www.ncbi.nlm.nih.gov/pubmed/19618069

208. Thriemer K, Ley B, Menten J, Jacobs J, van den Ende J. A systematic review and meta-analysis of the performance of two point of care typhoid fever tests, Tubex TF and Typhidot, in endemic countries. PLoS One. 2013;8: e81263. Available from: https://www.ncbi.nlm.nih.gov/pubmed/24358109

209. Afonso AM, Ebell MH, Tarleton RL. A systematic review of high quality diagnostic tests for Chagas disease. PLoS Negl Trop Dis. 2012;6:e1881. Available from: https://www.ncbi.nlm.nih.gov/pubmed/23145201

210. Mitashi P, Hasker E, Lejon V, Kande V, Muyembe JJ, Lutumba P, et al. Human african trypanosomiasis diagnosis in first-line health services of endemic countries, a systematic review. PLoS Negl Trop Dis. 2012;6:e1919. Available from: https://www.ncbi.nlm.nih.gov/pubmed/23209860

211. Odaga J, Sinclair D, Lokong JA, Donegan S, Hopkins H, Garner P. Rapid diagnostic tests versus clinical diagnosis for managing people with fever in malaria endemic settings. Cochrane Database Syst Rev. 2014:CD008998. Available from: https://www.ncbi.nlm.nih.gov/pubmed/24740584

212. Kabaghe AN, Visser BJ, Spijker R, Phiri KS, Grobusch MP, van Vugt M. Health workers' compliance to rapid diagnostic tests (RDTs) to guide malaria treatment: a systematic review and meta-analysis. Malar J. 2016;15:163. Available from: https://www.ncbi.n/m.nih.gov/pubmed/26979286

213. Whiting PF, Rutjes AW, Westwood ME, Mallett S, Deeks JJ, Reitsma JB, et al. QUADAS-2: a revised tool for the quality assessment of diagnostic accuracy studies. Ann Intern Med. 2011;155:529-36. Available from: https://www.ncbi. nlm.nih.gov/pubmed/22007046
Ready to submit your research? Choose BMC and benefit from:
- fast, convenient online submission
- thorough peer review by experienced researchers in your field
- rapid publication on acceptance
- support for research data, including large and complex data types
- gold Open Access which fosters wider collaboration and increased citations
- maximum visibility for your research: over $100 \mathrm{M}$ website views per year
At BMC, research is always in progress.
Learn more biomedcentral.com/submissions 